\author{
Robert Faracik \\ https://orcid.org/0000-0001-6795-7374 \\ Uniwersytet Pedagogiczny im. KEN w Krakowie \\ Instytut Geografii \\ robert.faracik@up.krakow.pl
}

\title{
ASPEKTY WIEJSKOŚCI W KRAJOBRAZIE KULTUROWYM DUŻEGO MIASTA NA PRZYKŁADZIE KRAKOWA
}

\begin{abstract}
Abstrakt: Celem artykułu jest charakterystyka wybranych aspektów wiejskości uwidaczniających się we współczesnym krajobrazie kulturowym Krakowa. Analizie poddano cztery aspekty tradycyjnie związane z krajobrazem wsi: wiejskie układy osadnicze, toponimię, użytkowanie gruntów i rolnictwo oraz wybrane elementy kultury ludowej. Zwrócono uwagę zarówno na przejawy wiejskości uwidaczniające się w formie materialnej, jak i stanowiące elementy dziedzictwa niematerialnego. W artykule podniesiono kwestię wielowymiarowości tego zjawiska i potrzebę interdyscyplinarnych badań w tej dziedzinie.
\end{abstract}

Słowa kluczowe: wiejskość, wieś, miejski krajobraz kulturowy, miasto, Kraków.

\section{ASPECTS OF RURALITY IN THE CULTURAL LANDSCAPE OF A LARGE CITY: A CASE STUDY OF KRAKÓW}

Abstract: The aim of the article is to describe selected aspects of rurality in the contemporary cultural landscape of Kraków. Four aspects traditionally associated with the rural landscape were analyzed: rural settlement systems, toponymy, land use and agriculture, and selected elements of folk culture. Attention was given both to manifestations of rurality visible in material forms and elements constituting intangible heritage. The article raises the issue of the multidimensional character of this phenomenon and the need for interdisciplinary research in this field

Keywords: rurality, countryside, urban cultural landscape, city, Kraków.

\section{WPROWADZENIE}

Termin „,wiejskość”, pochodzący bezpośrednio od przymiotnika „wiejski", w języku polskim charakteryzuje te cechy, które związane są bezpośrednio $\mathrm{z}$ wsia, rozumianą zarówno jako jednostka osadnicza, jak i swoiste przeciwieństwo miasta ( $\mathrm{w}$ tym także $\mathrm{w}$ znaczeniu przenośnym, często o konotacjach pejoratywnych). Zgodnie z definicją słownikową „wiejskość" można rozumieć jako „zespół cech charakterystycznych dla wsi i jej mieszkańców" (Wielki słownik języka polskiego, 2020b). Cechy te moga zatem m.in. określać: przynależność do wsi, właściwości charakterystyczne dla wsi i jej mieszkańców czy też wykonywanych przez nich czynności zawodowych, sprawowanych obowiązków rodzinnych i spełnianych funkcji społecznych.

Wiejskość jako antyteza miejskości była wyznacznikiem trwającego znaczną część XX w. modernistycznego podejścia do problemów osadniczych, społecznych i gospodarczych. Wykroczyła poza swoje konotacje geograficzne, nawiązujące do wzajemnych relacji przestrzennych wieś - miasto i traktujących wieś jako obiekt leżący poza miastem. Wiejskość zaczęła nabierać stopniowo cech konstruktu myślowego, pozbawionego odniesienia terytorialnego (Podedworna, 2013). Dlatego też często zaczęła być ona rozumiana jako synonim zacofania oraz uwstecznienia i ukazywana w kontraście do miasta i wszystkich pożytków wynikających z życia miejskiego. Słowo „wieśniak”, czyli pierwotnie mieszkaniec wsi/rolnik (Słownik jezzyka polskiego, 2020), stało się pogardliwym określeniem człowieka pochodzącego ze wsi lub mieszkającego na wsi, który nie potrafi odpowiednio się zachować (Wielki stownik języka polskiego, 2020a). Zmianie uległo także znaczenie pojęcia chłopa, nierozerwalnie związanego z tradycyjną wsią.

Badania geograficzne nad wiejskością odnoszą się głównie do wsi i obszarów wiejskich jako struktur o charakterze terytorialnym, w których zachodzą określone zjawiska i procesy uwidaczniające się $\mathrm{w}$ aspekcie przestrzennym tak $\mathrm{w}$ ujęciu statycznym, jak i dynamicznym. Analizie poddawane są m.in.: aspekty funkcji pełnionych przez te obszary, osadnictwo, demografia 
i zjawiska społeczne oraz gospodarcze. Uwidacznia się to w cechach, które przypisać można obszarom wiejskim (w odróżnieniu od cech miejskich), takich jak (Bański, 2012):

- specyficzny otwarty krajobraz,

- stosunkowo niska gęstość zaludnienia,

- przewaga ludności związanej z rolnictwem i leśnictwem,

- tradycyjny styl życia i zwyczaje,

- ekstensywne użytkowanie ziemi,

- rozproszone osadnictwo i rzadka zabudowa,

- przekonanie ludności, iż mieszka na wsi.

Geograficzne ujęcie wsi i obszarów wiejskich w sposób kompleksowy zawarte jest m.in. w pracach Bańskiego (2006, 2007, 2017) i Wójcika (2012, 2013).

Oddzielnym zagadnieniem jest kwestia stref podmiejskich, czyli obszarów leżących w sąsiedztwie dużych miast i powiązanych z nimi funkcjonalnie. Administracyjnie są to tereny przyległe do granic miasta, ale funkcjonalnie granice te są umowne. Miejscowości formalnie wiejskie poddawane są presji „,rozlewającego się" miasta (urban sprawl), w tym zmianom w strukturze użytkowania gruntów oraz przemianom demograficznym i społecznym (Szymańska, Biegańska, 2011). Ta swoista przejściowa forma, w zależności od sposobu i celu jej analizy, określana jest także jako kontinuum miejsko-wiejskie. Oddaje to bardziej jej charakter jako zjawiska, w którym obecność granicy administracyjnej miasta nie odgrywa większego znaczenia, a przejście z obszaru o charakterze miejskim do obszaru wiejskiego następuje stopniowo - tereny o charakterze wiejskim mogą znajdować się w granicach administracyjnych miasta, a wsie podmiejskie mogą być już zurbanizowane (Bański, 2008, 2012).

Silna urbanizacja Polski i innych krajów tzw. bloku wschodniego po II wojnie światowej, związana z postępującą industrializacją przyczyniła się do intensywnego ruchu migracyjnego ze wsi do miast, szczególnie do dużych i średnich ośrodków miejskich, w których silnie rozwijał się przemysł. Do dzisiaj znaczna część mieszkańców dużych miast pochodzi ze wsi lub jest kolejną generacją potomków tych migrantów (Nowakowski, 1963; Wasilewski, 1986). Drugim aspektem jest rozwój przestrzenny miast, wiążący się ze stałym poszerzaniem jego granic i stopniowym wchłanianiem obszarów podmiejskich tak $\mathrm{w}$ znaczeniu funkcjonalnym (pełnienie określonych funkcji dla miasta), jak i formalno-administracyjnym. Rozszerzanie się granic miasta jest zjawiskiem naturalnym, przy czym od drugiej połowy XIX w. proces ten znacząco się nasilił, co miało związek m.in. z modernizacją (sanacją) historycznych miast i podążaniem zgodnie $\mathrm{z}$ duchem nowoczesności, a także z potrzebą zagwarantowania odpowiedniej przestrzeni dla ich dalszego rozwoju (Szpakowska, 2011; Tkaczewski, 2016).
Faktem jest, że dawne wsie, które stały się częścią dużego miasta, wraz z upływem czasu nabierały cech miejskości, a ich zamknięte społeczności lokalne zostały poddane bezpośrednim wpływom innych centrów decyzyjnych. Stopniowe wyrównywanie dysproporcji w infrastrukturze technicznej oraz konsolidacja całej sfery życia społecznego i gospodarczego coraz mocniej wiązała je z ośrodkiem miejskim. Procesy te w poszczególnych przypadkach przebiegały w różnym tempie, a współczesny obraz dawnych obszarów wiejskich w dużej mierze wynika z czasu, który upłynął od chwili poszerzenia granicy miasta oraz odległości od jego centrum (peryferyjne położenie tych terenów). Urbanizacja przyczyniła się m.in. do przeobrażeń w samej przestrzeni i jej użytkowaniu, co uwidacznia się w zmianach fizjonomicznych na linii kontinuum miejsko-wiejskiego, oraz przekształcenia układów osadniczych miejscowości inkorporowanych w granice miasta. Analizą zachowania wiejskich historycznych układów osadniczych, które współcześnie znajdują się w obrębie dużych miast, zajmowali się m.in.: Cepil (2018); Chachaj (2014); Figlus (2020a, 2020b); Gajdek, Cieśla (2017); Gałka (2018); Miszewska, Szmytkie (2017); Szmytkie (2011, 2014); Wilkaniec (2018).

Jedną z podstawowych cech wyróżniających obszary wiejskie jest rolnictwo, będące tradycyjną formą aktywności zawodowej ich mieszkańców. Stan rolnictwa oraz tendencje $\mathrm{w}$ zakresie jego rozwoju $\mathrm{w}$ polskich miastach były $w$ ostatnich latach przedmiotem wielu analiz naukowych. Wymienić tu należy m.in. prace, takie jak: Grochulska-Salak (2017, 2018, 2019); Jeziorska-Biel, Wójcik (2017); Krzyk, Tokarczuk, Heczko-Hyłowa, Ziobrowski (2013); Sroka (2013, 2014a, 2014b, 2015, 2016a, 2016b); Sroka, Musiał (2016). Opracowania te dotyczyły zarówno rolnictwa w ujęciu tradycyjnym (rolnicze wykorzystanie użytków rolnych), jak i współczesnych form agrokultury, w tym nowatorskich rozwiązań w skali dzielnicowej, osiedlowej czy nawet indywidualnych działek-ogrodów oraz mieszkań w nowo powstających obiektach budownictwa wielorodzinnego (np. uprawy balkonowe, tarasowe). Ważnym zagadnieniem jest również funkcjonowanie na obszarze miast rodzinnych ogródków działkowych (Duś, 2011; Szkup, 2013; Szkup, Pytel, 2016).

„Wiejskość" jest terminem szerszym niż „wieś" $\mathrm{i}$ „obszar wiejski" i ma charakter wielowymiarowy, a badaniem tego zjawiska zajmują się przedstawiciele wielu dyscyplin naukowych, $\mathrm{w}$ tym: socjologii, antropologii, etnografii, kulturoznawstwa, geografii (Bański, 2012; Jeziorska-Biel, Wójcik, 2017). W badaniach naukowych problem wiejskości ${ }^{1}$ rozpatrywany jest zazwyczaj z punktu widzenia socjologicznego, mimo że jak zaznaczono wcześniej, pierwotnie odnosił się do konkretnych cech o charakterze przestrzennym (Górka, 2015; Halamska, 2009, 2011; Podedworna, 2010, 2013). 
Podobnie wielowymiarowy charakter ma pojęcie krajobrazu, w tym coraz powszechniej analizowana kwestia krajobrazu kulturowego. Temat ten jako przedmiot badań różnych dyscyplin naukowych może być nieco odmiennie pojmowany - przyjmując raz węższy, raz szerszy zakres znaczeniowy - od tradycyjnego ujęcia fizjonomicznego, po szeroko rozumiane zagadnienia kultury niematerialnej, stanowiącej uzupełnienie i dopełnienie kwestii uwidaczniających się w wizualnej jego odsłonie. Na krajobraz jako przedmiot badań różnych dyscyplin naukowych zwracają uwagę m.in.: Frydryczak (2011); Myga-Piątek (2001, 2005a, 2005b, 2012); Plit (2011, 2016).

Niezmiernie ważną kwestią jest relacja między człowiekiem a otaczającym go krajobrazem, co stanowi swoistą kwintesencję krajobrazu kulturowego, rozumianego jako „postrzeganą przez ludzi przestrzeń, zawierającą elementy przyrodnicze i wytwory cywilizacji, historycznie ukształtowaną w wyniku działania czynników naturalnych i działalności człowieka" (Ustawa, 2015). Na takie doświadczanie krajobrazu wpływ ma m.in. określone genius loci. Ten „duch miejsca” wynika z wielowiekowej historii, na którą składają się wydarzenia, ludzie oraz kształtowany pod ich wpływem świat wierzeń, przekonań i innych narracji kulturowych, decydujących o indywidualnym charakterze danego miejsca. Jak zauważa Michałowski (2001, s. 5)

w krajobrazie jest wyrażona jakość życia zamieszkującej go ludności, regionu, a w końcu całego kraju, jego poziomu cywilizacyjnego i kulturowego; w krajobrazie odciskają się procesy historyczne, które go kształtowały, stąd jest on świadectwem dorobku tej społeczności, a więc dziedzictwem, które winniśmy przekazywać następnym pokoleniom.

Charakterystyczną cechą krajobrazu kulturowego jest jego stratygrafia (Myga-Piątek, 2012), przejawiająca się w następujących po sobie fazach krajobrazu, zmieniających się pod wpływem czynników naturalnych, ale przede wszystkim historyczno-kulturowych. Jak podkreśla Bogdanowski (2001) krajobraz kulturowy stanowi wyraz gospodarczej działalności człowieka. Wszystkie niemal zjawiska związane z daną cywilizacja, stosunkami społecznymi, gospodarczymi itp. znajdują $\mathrm{z}$ reguły ważne odbicie $\mathrm{w}$ jego formach. Zauważa on również, że zachodzi także relacja odwrotna, zakładająca, że z krajobrazu odczytać można z zasady wszystkie wymienione właściwości. Zaznacza, że każdy fragment krajobrazu kulturowego powstał w wyniku długotrwałych przemian, przechodząc od typu krajobrazu pierwotnego, poprzez kolejne fazy krajobrazów historycznych, po współczesny krajobraz kulturowy. Dlatego też, w każdym krajobrazie kulturowym zachowały się - w różnym stanie i w różnej formie - ślady, a także konkretne pozostałości po kolejnych fazach jego przekształceń, które przynajmniej we fragmentach są możliwe do odczytania i oddziałują na właściwości oraz formę krajobrazu. Ten zespół właściwości Bogdanowski (2001) określił mianem „,tradycji miejsca”. W całej sekwencji nawarstwień (stratygrafii) można wyróżnić na danym obszarze fazy krajobrazu: pierwotnego, naturalnego oraz kulturowego (tak historycznego, jak i współczesnego).

Wiejskość krajobrazu można rozumieć dwojako. $Z$ jednej strony przejawiać się będzie jako dominujący wyznacznik krajobrazu, co w konsekwencji prowadzić będzie do wydzielenia krajobrazu charakterystycznego dla wsi, określanego mianem krajobrazu rolniczego (ze względu na dominującą formę gospodarowania, funkcję obszaru) (m.in. Myga-Piątek, 2012) lub krajobrazu wiejskiego (ze względu na określone cechy fizjonomiczne, np. cechy środowiska naturalnego, osadnictwo, budownictwo, formy użytkowania ziemi) (m.in. Jędrysiak, 2010; Wieczorkiewicz, 1995). Z drugiej strony, przyjmując założenia Bogdanowskiego (1996, 2001), poszczególnych śladów wiejskości można doszukiwać się we współczesnym krajobrazie kulturowym różnych jednostek przestrzennych traktowanym ogólnie, lub w poszczególnych typach krajobrazów kulturowych wydzielanych na podstawie przyjętych kryteriów funkcjonalnych (np. w obrębie krajobrazu: rolniczego i pasterskiego, osadniczego, gospodarki leśnej, górniczego, przemysłowego, poeksploatacyjnego, turystycznego i rekreacyjnego, religijnego i sakralnego) (Myga-Piątek, 2012). Tyczy się to także dużych miast i aglomeracji miejskich, w historii można wyróżnić okresy związane z ich rozwojem jako wsi (zazwyczaj w fazie inicjalnej) lub wiejskich jednostek osadniczych, które z upływem czasu znalazły się w ich granicach. Także funkcje charakterystyczne dla obszarów wiejskich, jak rolnictwo, leśnictwo czy myślistwo i łowiectwo stanowiły w przeszłości ważny aspekt życia gospodarczego tych jednostek, co sprawia, że we współczesnym krajobrazie kulturowym miast dostrzec można różne aspekty związane z wiejskością. Dodatkowo miasta pełniły i pełnią dla ludności wiejskiej określone funkcje, z czym także wiążą się specyficzne akcenty w całościowo rozumianym krajobrazie kulturowym (np. place targowe, giełdy rolno-spożywcze). Istotna jest także rola i znaczenie miasta w pełnieniu określonych funkcji (np. nauka i edukacja w zakresie wsi i rolnictwa; miasto jako ośrodek ruchu ludowego; miasto jako ośrodek życia społecznego i aktywności gospodarczej społeczności wiejskich; działy administracji w zakresie wsi i rolnictwa i in.). Tym sposobem aspekty wiejskości krajobrazu kulturowego miasta mogą mieć charakter endogeniczny i wiązać się z tradycjami wiejskimi ukształtowanymi w obrębie samego miasta oraz egzogeniczny, związany z funkcjami, jakie miasto pełni w strukturach przestrzennych na szczeblu lokalnym, regionalnym, krajowym, a także międzynarodowym, 
Tabela 1. Podejścia badawcze w zakresie wiejskości jako czynnika kształtującego krajobraz i jako składowej krajobrazu kulturowego miasta

\begin{tabular}{|c|c|}
\hline Podejście & Główny zakres badań \\
\hline Podejście geograficzne & $\begin{array}{l}\text { Badania i analizy przestrzenne związane m.in. z aspektami przyrodniczymi, zagospodarowaniem } \\
\text { i użytkowaniem gruntów, fizjonomią krajobrazu, zmianami przestrzennymi w czasie }\end{array}$ \\
\hline Podejście historyczne & $\begin{array}{l}\text { Wiejskość i jej przemiany w czasie: geneza, przebieg zjawisk w czasie, wzajemne relacje } \\
\text { przyczynowo-skutkowe zjawisk i ich reprezentacja w krajobrazie kulturowym }\end{array}$ \\
\hline Podejście humanistyczne & $\begin{array}{l}\text { Zagadnienie wiejskości i krajobrazu kulturowego w ujęciu filozoficznym (np. estetycznym, } \\
\text { aksjologicznym), językoznawczym (np. onomastyka), literaturoznawczym, sztuk plastycznych, } \\
\text { muzyki itp. Aspekty psychologiczne }\end{array}$ \\
\hline Podejście ekonomiczne & $\begin{array}{l}\text { Wiejskość i jej związki z funkcją gospodarczą. Znaczenie rolnictwa i innych form gospodarowania } \\
\text { związanych z wsią w gospodarce miasta. Relacje między gospodarką a krajobrazem kulturowym }\end{array}$ \\
\hline Podejście socjologiczne & $\begin{array}{l}\text { Badania i analizy zjawiska wiejskości w odniesieniu do kwestii społecznych, m.in.: zachowanie } \\
\text { tradycji i zwyczajów, tożsamość lokalna, relacje swoi-obcy, postrzeganie krajobrazu }\end{array}$ \\
\hline Podejście instytucjonalne & $\begin{array}{l}\text { Poznanie i analiza celów i sposobów działania różnych instytucji odpowiedzialnych za sprawy } \\
\text { wsi i rolnictwa oraz krajobrazu (w tym krajobrazu kulturowego) }\end{array}$ \\
\hline Podejście kulturowe & $\begin{array}{l}\text { Analiza kwestii wiejskości w szeroko rozumianej kulturze, wpływu współczesnej kultury na } \\
\text { jej przemiany oraz relacji między aspektami kulturowymi a krajobrazem. Kultura ludowa i jej } \\
\text { przejawy }\end{array}$ \\
\hline Podejście organizacyjne & $\begin{array}{l}\text { Koncentracja na zagadnieniach organizacji i zarządzania w obrębie problemów wsi i rolnictwa } \\
\text { oraz kształtowania krajobrazu (w tym krajobrazu kulturowego) }\end{array}$ \\
\hline Podejście systemowe & $\begin{array}{l}\text { Łączenie różnych podejść w jedną złożoną metodę oceny zjawiska wiejskości jako systemu lub } \\
\text { podsystemu w szerszym ujęciu (np. całego miasta, regionu). Traktowanie wiejskości i krajobrazu } \\
\text { kulturowego jako systemu wzajemnie połączonych i wpływających na siebie elementów }\end{array}$ \\
\hline Podejście prognostyczne & $\begin{array}{l}\text { Wpływ tempa zmian zjawisk związanych z wiejskością na aspekty przyrodnicze, społeczne, } \\
\text { ekonomiczne i kulturowe w przyszłości }\end{array}$ \\
\hline Podejście interdyscyplinarne & $\begin{array}{l}\text { Próba odpowiedzi na stawiane pytania i problemy badawcze z zakresu wiejskości i krajobrazu } \\
\text { kulturowego z punktu widzenia różnych dyscyplin naukowych }\end{array}$ \\
\hline Podejście transdyscyplinarne & $\begin{array}{l}\text { Poszukiwanie rozwiązań problemówbadawczychw zakresiewiejskościikrajobrazukulturowego } \\
\text { nie tylko w obrębie pola badawczego konkretnej dyscypliny, ale również wykraczanie poza } \\
\text { przyjęte jej centrum zainteresowań w celu interakcji z peryferiami innych dyscyplin naukowych }\end{array}$ \\
\hline
\end{tabular}

Źródło: opracowanie własne.

a które łączą się z szeroko pojmowaną problematyką wsi i rolnictwa.

Na poszczególne aspekty wiejskości można spojrzeć przez pryzmat różnych dziedzin i dyscyplin nauki, w obrębie których wypracowano właściwy im aparat pojęciowy i metodologiczny. Pozwala to na wyróżnienie zasadniczych podejść badawczych do zjawiska wiejskości jako czynnika kształtującego krajobraz i jako elementu składowego krajobrazu kulturowego miasta (tab. 1).

Współcześnie wiejskość zaczęła być postrzegana jako zjawisko będące przeciwieństwem mankamentów życia miejskiego, na nowo podkreślać zaczęto idylliczność i sielskość krajobrazu, możliwość bezpośredniego kontaktu z przyroda, zwraca się również uwagę naznaczenie więzi społecznych w kontekście anonimowości życia miejskiego. Ma to istotny wpływ nie tylko na rewizję dotychczasowych poglądów na wiejskość, ale także staje się przyczynkiem zmian w środowisku miejskim, które przyjmuje coraz częściej rozwiązania rodem ze wsi.

Celem artykułu jest charakterystyka wybranych aspektów wiejskości we współczesnym krajobrazie kulturowym dużego miasta w ujęciu interdyscyplinarnym. Analizie poddano cztery aspekty tradycyjnie związane z krajobrazem kulturowym wsi: wiejskie układy osadnicze, toponimię, użytkowanie gruntów i rolnictwo oraz wybrane elementy kultury ludowej. Zwrócono uwagę zarówno na przejawy wiejskości uwidaczniające się w formie materialnej, jak i stanowiące elementy dziedzictwa niematerialnego. Poszczególne kwestie omówiono na przykładzie Krakowa. Praca opiera się na analizie materiałów źródłowych, takich jak: mapy katastralne archiwalne (kataster austriacki) i aktualne ${ }^{2}$, mapy topograficzne archiwalne i aktualne oraz ortofotomapy ${ }^{3}$, dokumenty planistyczne i inne dokumenty z zasobów archiwum Urzędu Miasta Krakowa (m.in. obowiązujące Studium uwarunkowań i kierunków zagospodarowania przestrzennego Miasta Krakowa, Opracowanie Ekofizjograficzne Miasta Krakowa), Rejestr Urzędowy Podziału Terytorialnego Kraju (TERYT), Państwowy Rejestr Nazw Geograficznych (w ramach Głównego Urzędu Geodezji i Kartografii), opracowania kartograficzne w ramach Małopolskiej Infrastruktury Informacji Przestrzennej MIIP (Małopolski Urząd Marszałkowski), akty prawne oraz literatura przedmiotu 
uzyskane w wyniku przeprowadzonej kwerendy bibliotecznej. Materiał źródłowy został dodatkowo uzupełniony wynikami badań terenowych.

\section{HISTORYCZNE UKŁADY OSADNICZE (RURALISTYCZNE) \\ W GRANICACH ADMINISTRACYJNYCH KRAKOWA JAKO ŚWIADECTWO WIEJSKIEJ PRZESZŁOŚCI}

Historyczne układy osadnicze należą do najbardziej trwałych i czytelnych elementów pierwotnego układu przestrzennego i funkcjonalnego wsi i innych jednostek (np. jurydyk), które weszły w granice większego miasta. Ich znaczenie dla krajobrazu kulturowego potwierdza fakt, że zostały uwzględnione w Ustawie o ochronie zabytków i opiece nad zabytkami (Ustawa, 2003), definiującej je jako „przestrzenne założenie miejskie lub wiejskie, zawierające zespoły budowlane, pojedyncze budynki i formy zaprojektowanej zieleni, rozmieszczone w układzie historycznych podziałów własnościowych i funkcjonalnych, w tym ulic lub sieci dróg". Jak zaznaczono wcześniej, stopniowe rozciąganie granic miasta wraz z upływem czasu powoduje, że najlepiej zachowane i najbardziej czytelne układy ruralistyczne znajdują się współcześnie na jego peryferiach.

Poszerzanie granic Krakowa rozpoczęło się w 1792 r., kiedy to do miasta znajdującego się w obrębie murów miejskich (granice średniowiecznego lokacyjnego Krakowa) formalnie włączono rozwijające się w sąsiedztwie jurydyki. Zabieg ten był wynikiem regulacji Sejmu Czteroletniego. Jurydyki jako specyficzne formy osadnicze i funkcjonalne nie posiadały statusu miast. Dzisiaj zaś stanowią centralnie położone fragmenty Krakowa, w których doszukać się można zarysu rozwijającego się przed wiekami układu funkcjonalnego, o którym świadczą np.: główne kierunki ulic (dawnych dróg) i placów (place targowe), świątynie (często późniejsze, w miejscu pierwotnie usytuowanych obiektów kultu) oraz kapliczki przydrożne czy kamienie graniczne. Główną jednak pozostałością są toponimy, odnoszące się bezpośrednio do nazwy dawnej jurydyki bądź do jej części, pełniących określone funkcje. W granice Krakowa weszły wówczas także dwa ośrodki miejskie, rozwijające się dotąd niezależnie: Kleparz i Kazimierz (Poczet Krakowski, 2020a).

Zmiany, jakie nastąpiły w Europie w drugiej połowie XIX w., zmusiły władze państwowe i miejskie do poszukiwania rozwiązań, pozwalających na sprostanie wymaganiom wynikającym $z$ dynamicznego rozwoju miast, które weszły na drogę rozwoju zgodnego z paradygmatem nowoczesności. Najczęściej wprowadzane rozwiązania polegały na przebudowach centrów miast (np. tzw. wielka przebudowa Paryża w latach 1852-1870 lub asanacja praska na przełomie XIX i XX w.) oraz na poszerzaniu ich granic. W 1915 r. weszły w życie przepisy wynikające z realizacji „Planu regulacyjnego Wielkiego Krakowa" - do którego przyłączono kilkanaście sąsiadujących $\mathrm{z}$ nim miejscowości, $\mathrm{w}$ tym miasto Podgórze. Obecnie dawne układy ruralistyczne tych miejscowości zachowały się w sposób szczątkowy, choć w niektórych przypadkach nadal są dobrze widoczne w obrębie swoistych enklaw, leżących nawet $w$ centrum miasta (np. Ludwinów z ostatnimi drewnianymi domami położonymi w centrum Krakowa) (fot. 1).

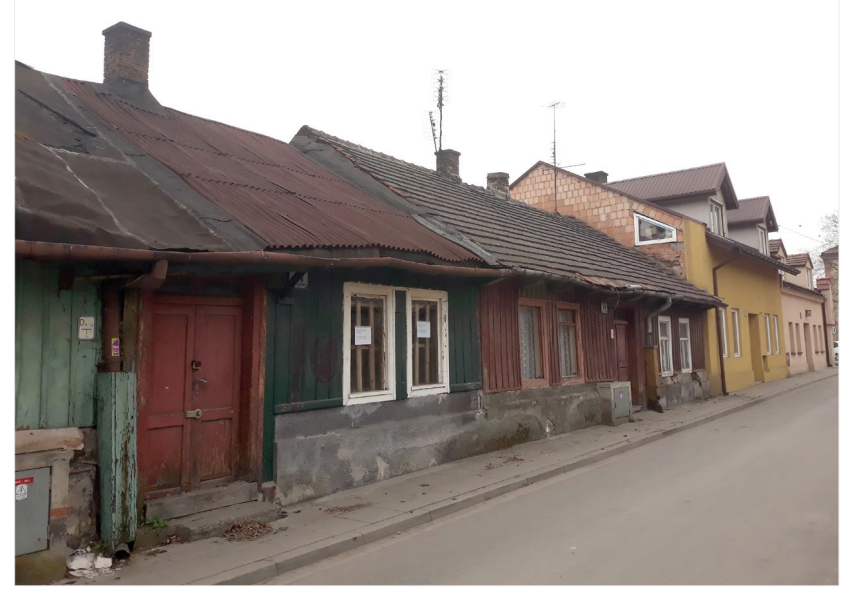

Fotografia 1. Drewniane domy w Ludwinowie przy ul. Tureckiej

Źródło: R. Faracik (22.03.2019)

Kolejny etap rozszerzania granic miał miejsce w $1941 \mathrm{r}$. Wówczas okupacyjne władze niemieckie przyłączyły do miasta 30 miejscowości, które stały się odpowiednio kolejnymi dzielnicami katastralnymi. W 1948 r. władze polskie, w drodze rozporządzenia Rady Ministrów o zmianie granic miasta Krakowa, potwierdziły dokonane wcześniej przez władze niemieckie powiększenie powierzchni miasta, jednocześnie nadając rozporządzeniu wsteczną moc obowiązującą od 18 stycznia 1945 r. W przypadku tych dzielnic dawny układ ruralistyczny w znacznej części przetrwał $w$ formie reliktowej, do czego przyczyniło się szybko rozwijające się na tym obszarze budownictwo mieszkaniowe. W niektórych przypadkach (dzielnice położone skrajnie peryferyjnie) układy te zachowały się w sposób czytelny (np. stara część Borku Fałęckiego, Bronowice Małe, część Witkowic, Tonie) (tab. 2, rys. 1).

W 1951 r. nastąpiło zwiększenie powierzchni Krakowa w wyniku realizacji projektu Nowej Huty. Wówczas wcielonych do miasta zostało kilkanaście wsi, leżących bezpośrednio na wschód od dotychczasowego miasta. Stopniowa rozbudowa Nowej Huty wraz z kombinatem metalurgicznym przyczyniła się do urbanizacji i industrializacji tej części miasta, a co za tym idzie również 
Tabela 2. Etapy przyłączania kolejnych miejscowości w granice miasta Krakowa

\begin{tabular}{|c|c|c|c|c|}
\hline Etap & Rok & $\begin{array}{l}\text { Powierzchnia } \\
\text { miasta }\left(\mathrm{km}^{2}\right)\end{array}$ & $\begin{array}{l}\text { Liczba ludności } \\
\text { (tys.) }\end{array}$ & Miejscowości i ich części przyłączone do Krakowa \\
\hline I & do 1792 & 0,9 & $11,6^{*}$ & Kraków lokacyjny (w obrębie murów obronnych), Wawel \\
\hline II & 1792 & 46,9 & 183,0 & $\begin{array}{l}\text { Smoleńsk, Retoryka, Garbary-Piasek, Biskupie, Wesoła-Piaski, Stra- } \\
\text { dom, byłe miasto Kazimierz, byłe miasto Kleparz }\end{array}$ \\
\hline III & 1915 & 49,5 & 207,0 & $\begin{array}{l}\text { Ludwinów, Zakrzówek, Dębniki, Półwsie Zwierzynieckie, Zwierzyniec, } \\
\text { Czarna Wieś, Nowa Wieś Narodowa, Łobzów, Krowodrza, Warszawskie } \\
\text { (z części gmin Prądnik Czerwony i Olsza), Grzegórzki, Dąbie, Płaszów, } \\
\text { Podgórze }\end{array}$ \\
\hline IV & 1941 & 165,3 & 285,0 & $\begin{array}{l}\text { Łagiewniki, Jugowice, Borek Fałęcki, Kobierzyn, Skotniki, Pychowice, } \\
\text { Bodzów, Kostrze, Przegorzały, Bielany, Wola Justowska, Chełm, Brono- } \\
\text { wice Małe, Bronowice Wielkie, Tonie, Prądnik Biały, Witkowice, Górka } \\
\text { Narodowa, Prądnik Czerwony, Olsza, Rakowice, Czyżyny, Łęg, Rybitwy, } \\
\text { Rżąka, Prokocim, Wola Duchacka, Piaski Wielkie, Kurdwanów, część Bie- } \\
\text { żanowa i Bieńczyc }\end{array}$ \\
\hline $\mathrm{V}$ & 1951 & 229,9 & 355,0 & $\begin{array}{l}\text { Mogiła z Kopańcem i Kępą Przewozu, pozostała część Bieńczyc, Mi- } \\
\text { strzejowice, Zesławice z Dłubnia, Kantorowice, Krzesławice, Grębałów, } \\
\text { Lubocza, Wadów, Pleszów z Kujawami, Ruszcza, Branice z Chałupkami, } \\
\text { Holendrami i Wolą Rusiecką }\end{array}$ \\
\hline VI & 1973 & 322,3 & 657,3 & $\begin{array}{l}\text { Kosocice z Barycza, Soboniowice, Rajsko, Wróblowice, Swoszowice, Opat- } \\
\text { kowice, Sidzina, Tyniec z Podgórkami, Olszanica, Mydlniki, Łuczanowice, } \\
\text { Kościelniki, Wolica z Rogowem, Przylasek Wyciąski, Wyciąże, Przylasek } \\
\text { Rusiecki, Przewóz, pozostała część Bieżanowa, północna częśc Zbydnio- } \\
\text { wic, części Batowic, część Libertowa, część Lusiny }\end{array}$ \\
\hline VII & 1986 & 326,8 & 743,7 & Węgrzynowice, Wróżenice, południowa część Zbydniowic, część Dzikanowic \\
\hline$-{ }^{* *}$ & 2013 & 326,8 & 758,3 & część wsi Zastów \\
\hline
\end{tabular}

Objaśnienia: * w 1787 r.; ** korekta granicy.

Źródło: Luchter (2012), Mydel (1979, 1994), Poczet Krakowski (2020b, 2020c, 2020d).

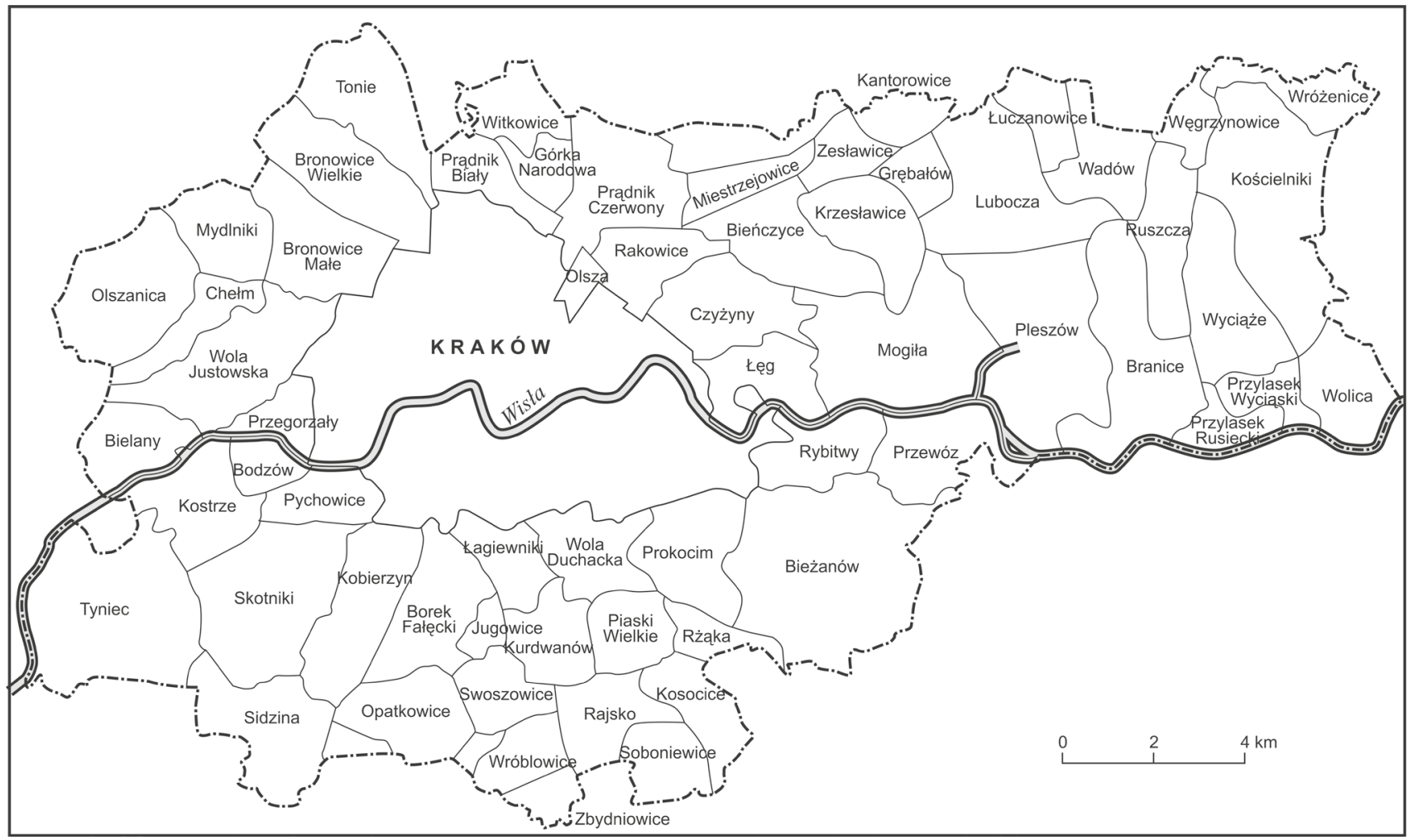

Rysunek 1. Wsie przyłączone do Krakowa po 1915 r.

Źródło: Poczet Krakowski (2020c) 
do przekształcenia lub zaniku dotychczasowych układów osadniczych. Pośród osiedli mieszkaniowych powstałych na obszarze tych wsi zachowały się jednak elementy dawnej struktury osadniczej (m.in. układy dróg, elementy hydrotechniczne, stare zabudowania). Przykładami mogą być w tym przypadku stare części Mogiły, Grębałowa i Pleszowa (tab. 2).

Kolejny etap rozwoju terytorialnego miasta przypada na 1973 r., kiedy to do Krakowa włączono pierścień wsi okalających dotąd miasto. Mimo upływu blisko 50 lat od tego momentu większość tych jednostek zachowała swój układ przestrzenny, który stał się trzonem współczesnego układu osadniczego. Kontynuacją tego procesu było poszerzenie granic miasta w 1986 r. o dalsze trzy miejscowości. Ostatnią zmiana, w 2013 r., była niewielka korekta granicy miasta (4,6 ha) z wsią Zastów (tab. 2).

Analizując stan zachowania i czytelność poszczególnych układów ruralistycznych w obrębie miasta, można wyróżnić kilka charakterystycznych typów:

- układy niezachowane, ale obecne w postaci toponimii (nazwy dzielnic, ulic, placów i in.);

- układy reliktowe z zachowanymi pojedynczymi elementami struktury sieci drogowej;
- układy reliktowe z zachowanymi pojedynczymi elementami struktury sieci drogowej oraz budynkami i parcelacją (fot. 1, rys. 2);

- układy reliktowe $\mathrm{z}$ zachowaną dominantą przestrzenną (np.: pałac, zamek, klasztor, kościół, dwór/ zespól dworski);

- układy czytelne z zachowaną parcelacją, rozłogiem pól i zabudową o charakterze wiejskim;

- układy czytelne z zachowaną parcelacja, rozłogiem pól, zabudową o charakterze wiejskim wraz z dominantą przestrzenną (rys. 3).

Wśród dominant przestrzennych szczególna rola przypada: zespołom klasztornym (Tyniec, Mogiła), dworom i zespołom dworskim (m.in. Łuczanowice, Kościelniki, Ruszcza, Wadów, Prądnik Biały, Pleszów, Branice, Krzesławice, Bronowice Małe), pałacom (m.in. Prokocim, Wola Justowska), zamkom (zamek królewski na Łobzowie z jego późniejszymi przekształceniami) i kościołom. Oddzielną grupę obiektów tworzą dawne fortyfikacje austriackie, które stanowią ważny element przestrzeni dzisiejszych osiedli, a dawnych wsi. Ciekawym przykładem dominanty przestrzennej jest zabytkowy zespół szpitala psychiatrycznego w Kobierzynie (nadal funkcjonujący w tym miejscu).

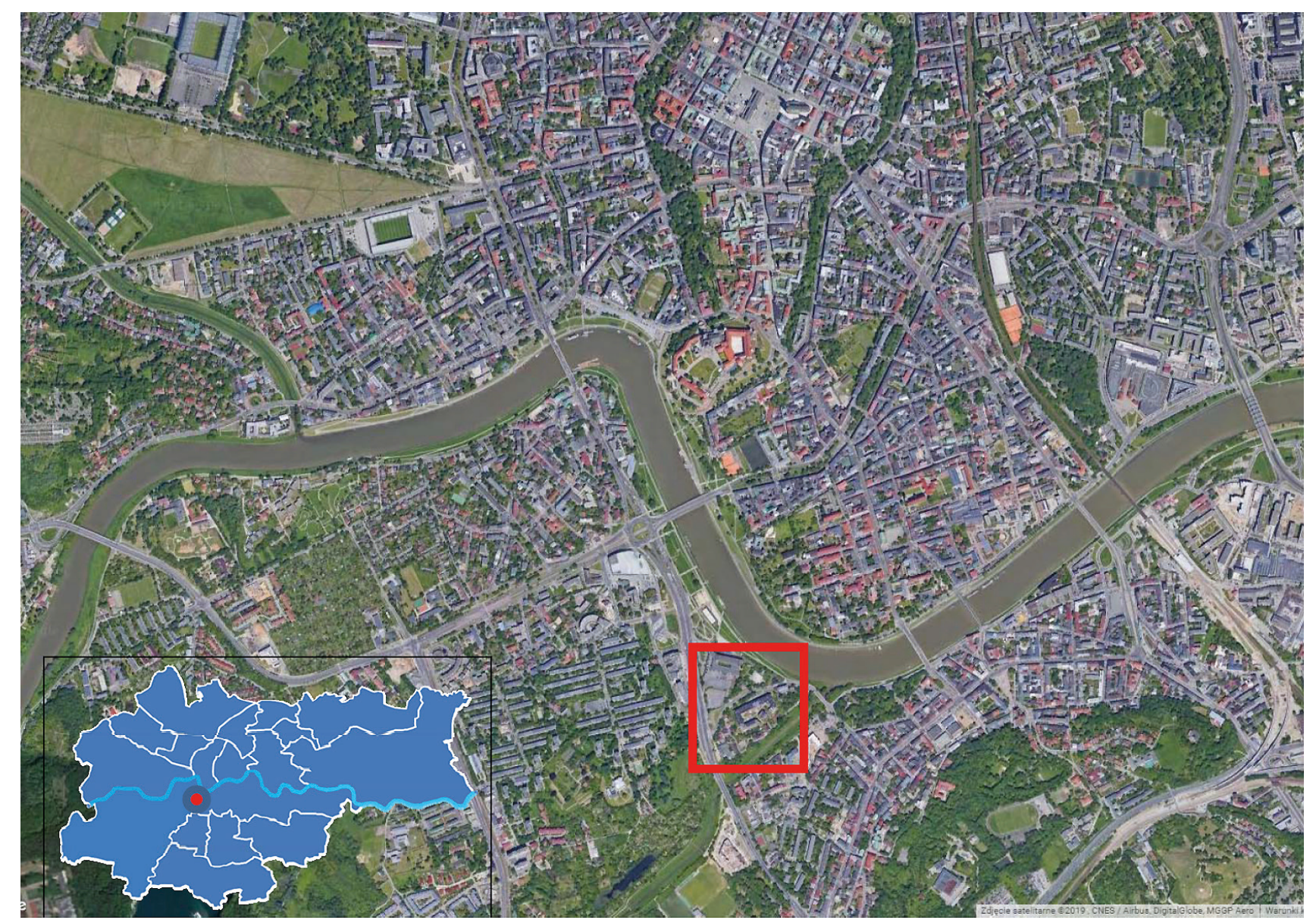

Rysunek 2. Ludwinów - przykład układu reliktowego w formie enklawy położonej w centrum miasta Źródło: opracowanie własne na podstawie zasobów Google Maps (2019) 


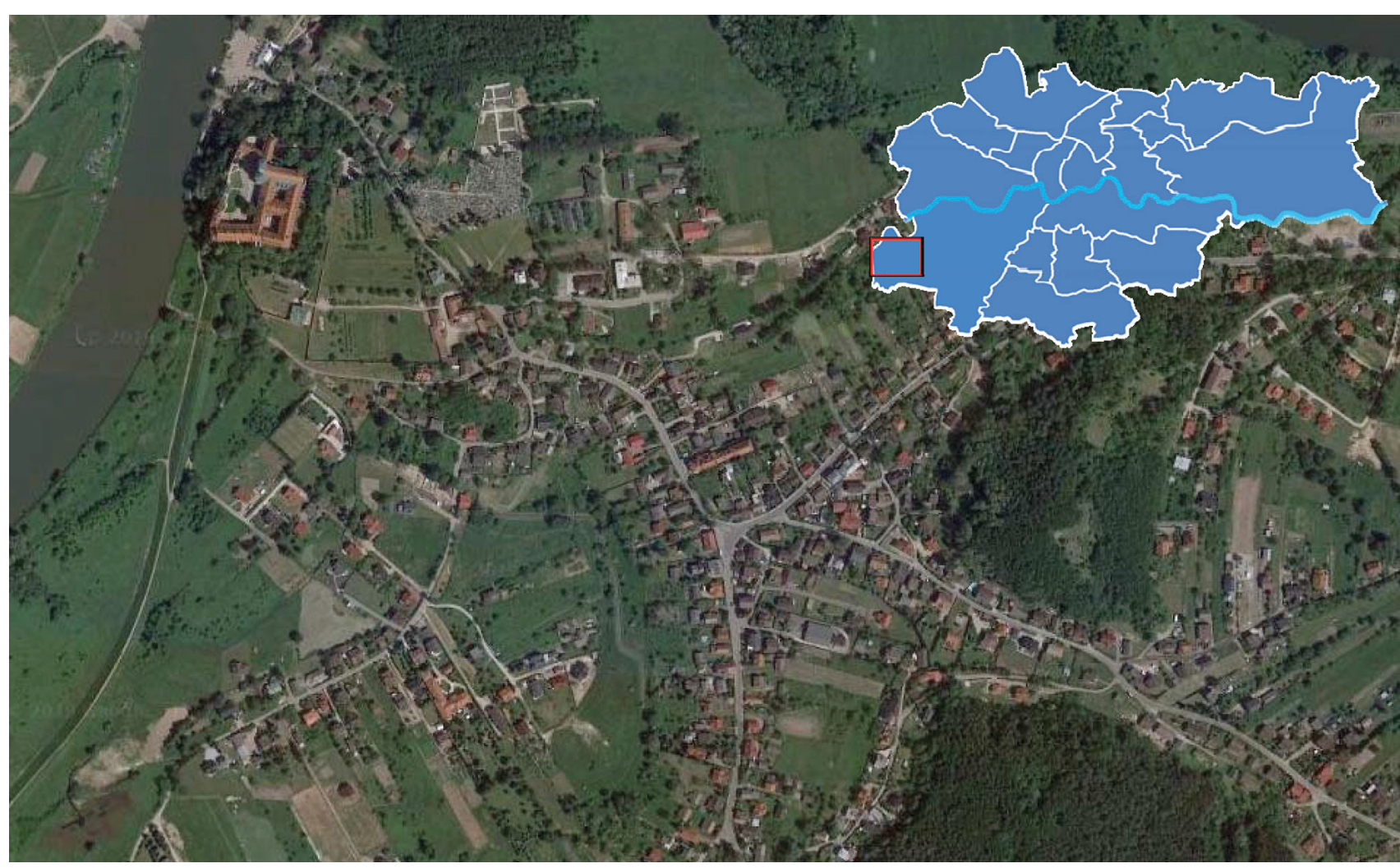

Rysunek 3. Tyniec - przykład czytelnego układu ruralistycznego Źródło: opracowanie własne na podstawie zasobów Google Maps (2019)

Analizując sposób włączenia historycznego układu ruralistycznego we współczesny system osadniczy miasta, wyróżniono trzy zasadnicze typy:

- układy niezachowane, w całości zastąpione późniejszym osadnictwem i siecią drogową;

- układy, z których pojedyncze elementy weszły do struktury współczesnego układu osadniczego (np. pojedyncze ulice i place);

- układy, z których większość elementów weszła do struktury współczesnego układu osadniczego. W grupie tej wyróżnić można te układy historyczne, które stanowią trzon współczesnych układów osadniczych (układy rozrosłe).

Niestety brak bezpośredniej ochrony zabytkowych układów ruralistycznych w obrębie aglomeracji miejskich powoduje, że niejednokrotnie unikatowe elementy krajobrazu lokalnego bezpowrotnie przemijają ${ }^{4}$.

Z historycznymi układami osadniczymi związane jest także tradycyjne budownictwo, którego pozostałości znajdują się jeszcze na obszarze Krakowa, w tym drewniane domy wybudowane w XIX w. Zachowały się one jeszcze $\mathrm{w}$ peryferyjnie położonych osiedlach Krakowa, m.in. w Bronowicach, Borku Fałęckim, Jugowicach czy dawnych wsiach otaczających kombinat metalurgiczny w Nowej Hucie. Po II wojnie światowej powstała idea zorganizowania w Krakowie muzeum skansenowskiego, a na jego miejsce wybrano Wolę Justowską. Po pożarze w 2002 r., który strawił zabytkowy drewniany kościół z Komorowic (odbudowany po wcześniejszym pożarze w 1978 r.), dzisiejszy zespół budownictwa drewnianego składa się z karczmy z Pasieki koło Czernichowa i spichlerza z Trzyciąża. Obecnie odżyła myśl o skansenie, którego organizatorem jest spółka Kraków Nowa Huta Przyszłości S.A. Planuje się, że będzie on częścią większego przedsięwzięcia pod nazwą Park Edukacyjny „Branice” i docelowo pomieści przykłady zagród wiejskich z terenu Krakowa. Otwarcie parku w Branicach planowane jest na 2023 r. Ponadto na szczególną uwagę zasługują zabytkowe drewniane kościoły, m.in. w: Górce Kościelnickiej, Krzesławicach i Mogile.

\section{TOPONIMIA KRAKOWA JAKO ELEMENT NIEMATERIALNEGO DZIEDZICTWA DAWNYCH WSI}

$\mathrm{Z}$ osadnictwem nierozerwalnie związana jest toponimia. Wraz z wejściem obszarów wiejskich w granice miasta, nazwy miejscowe (m.in. sama nazwa miejscowości, nazwy jej części czy też obiektów fizjograficznych w obrębie wsi) stały się elementem urbanonimii (Handke, 1992). Toponimia, podobnie jak układ osadniczy, należy do najbardziej trwałych 
aspektów związanych z dawnym osadnictwem, a nazwy poszczególnych osad, wsi, miejscowości (i ich części) często przekształciły się w nazwy dzielnic czy osiedli. W przypadku Krakowa spośród aktualnych 18 dzielnic samorządowych aż 15 swoją nazwą nawiązuje bezpośrednio do wsi znajdujących się wcześniej na ich obszarze (w tym Podgórze jako dawne oddzielne miasto). Należy zaznaczyć, że we wcześniejszych latach liczba dzielnic, a co za tym idzie i ich nazw była różna. Przykładowo w latach 1909-1954 wydzielono 64 dzielnice katastralne (tab. 3, rys. 1), których nazwy były zgodne z nazwami dawnych wsi, jurydyk oraz miast, a nowy podział nawiązywał do granic istniejących wcześniej jednostek. W 1954 r. $\mathrm{w}$ ich miejsce utworzono 6 dzielnic (Stare Miasto, Grzegórzki, Kleparz, Podgórze, Zwierzyniec, Nowa Huta), a po rozszerzeniu granic miasta w 1973 r. wydzielono 4 wielkie dzielnice (Śródmieście, Krowodrza, Podgórze, Nowa Huta), które w 1991 r. przekształcono w 18 aktualnych dzielnic samorządowych.

Dawna toponimia uwidacznia się także w nazwach innych jednostek ujętych w aktach normatywnych i oficjalnych dokumentach planistycznych. Przykładem może być Krajowy Rejestr Urzędowy Podziału Terytorialnego Kraju (TERYT), w którym nadal funkcjonuje podział nawiązujący do obowiązującego przed $1991 \mathrm{r}$. podziału na 4 dzielnice. $Z$ kolei na potrzeby planowania i gospodarki miejskiej Kraków został podzielony na 63 strukturalne jednostki urbanistyczne, w których także uwidoczniona została $\mathrm{w}$ dużej mierze dawna toponimia miejska (tab. 4). Znacznie szerszy zakres toponimów obejmuje Państwowy Rejestr Nazw Geograficznych.

Oddzielną kategorię urbanonimów tworzą nazwy ulic i placów. Także w tym przypadku liczba nazw, które swój źródłosłów mają w dawnej toponimii wiejskiej, jest znacząca. Dokonując analizy ich pochodzenia, wyróżniono:

- nazwy odmiejscowe, związane z usytuowaniem $\mathrm{w}$ miejscu ulicy/placu lub $\mathrm{w}$ ich bezpośrednim sąsiedztwie określonej osady/wsi/jurydyki (np. ul. Białoprądnicka, ul. Bodzowska, ul. Bonarka, ul. Czarnowiejska);

- nazwy kierunkowe, nawiązujące do dróg/ulic wiodących w kierunku obiektów (np. ul. Krowoderska, ul. Łobzowska, ul. Mogilska, ul. Prądnicka, ul. Zwierzyniecka);

- nazwy wywodzące się od nazw części wsi (przysiółki, kolonie itp.), dawnych majątków ziemskich, folwarków, ról, niw i in. (np. pl. Bawół, ul. Chmieleniec, ul. Facimiech, ul. Duża Góra, ul. Ujastek);

- nazwy związane z działalnością gospodarczą (w tym rolniczą) prowadzoną w obrębie dawnych wsi (np. ul. Kosiarzy, ul. Młynowa, ul. Oraczy, ul. Przegon, ul. Włóczków);

- nazwy nawiązujące do obiektów istniejących w obrębie wsi (np. ul. Dworska, ul. Dworski Ogród, ul. Podedworze, ul. Folwarczna, ul. Gajówka);

- nazwy wywodzące się od obiektów fizjograficznych zarówno tych wyróżniających się wyraźnie w krajobrazie, jak i ważnych dla mieszkańców (np. ul. Jeziorko, ul. Kaimska, ul. Krzemionki, ul. Panieńskich Skał, ul. Suchy Jar);

- nazwy związane z wydarzeniami historycznymi, ze znanymi postaciami powiązanymi z miejscowościami, z osobami, które wpisały się na trwałe $\mathrm{w}$ życie lokalnych społeczności (np. ul. 28 lipca 1943 r., ul. Jadwigi z Łobzowa, ul. Klemensa z Ruszczy, ul. Ofiar Dąbia, ul. Poległych w Krzesławicach);

Tabela 3. Dzielnice katastralne Krakowa w latach 1909-1954

\begin{tabular}{|c|c|c|}
\hline \multicolumn{3}{|c|}{ Dzielnice katastralne } \\
\hline do $1941 \mathrm{r}$. & $\begin{array}{l}\text { utworzone po rozszerzeniu granic miasta } \\
\text { w } 1941 \mathrm{r} \text {. }\end{array}$ & $\begin{array}{l}\text { utworzone po rozszerzeniu granic miasta } \\
\text { w } 1951 \mathrm{r} \text {. }\end{array}$ \\
\hline $\begin{array}{l}\text { I - Śródmieście, II - Wawel, } \\
\text { III - Nowy Świat, IV - Piasek, } \\
\text { V - Kleparz, VI - Wesoła, } \\
\text { VII - Stradom, VIII - Kleparz, } \\
\text { IX - Ludwinów, X - Zakrzówek, } \\
\text { XI - Dębniki, XII - Półwsie } \\
\text { Zwierzynieckie, XIII - Zwierzyniec, } \\
\text { XIV - Czarne Wieś, XV - Nowa } \\
\text { Wieś, XVI - Łobzów, } \\
\text { XVII - Krowodrza, } \\
\text { XVIII - Warszawskie, } \\
\text { XIX - Grzegórzki, XX - Dabie, } \\
\text { XXI - Płaszów, XXII - Podgórze }\end{array}$ & $\begin{array}{l}\text { XXIII - Łagiewniki, XXIV - Jugowice, } \\
\text { XXV - Borek Fałęcki, XXVI - Kobierzyn, } \\
\text { XXVII - Skotniki, XXVIII - Pychowice, } \\
\text { XXIX - Bodzów, XXX - Kostrze, } \\
\text { XXXI - Przegorzały, XXXII - Bielany, } \\
\text { XXXIII - Wola Justowska, XXXIV - Chełm, } \\
\text { XXXV - Bronowice Małe, } \\
\text { XXXVI - Bronowice Wielkie, } \\
\text { XXXVII - Tonie, XXXVIII - Prądnik Biały, } \\
\text { XXXIX - Witkowice, XL - Górka Narodowa, } \\
\text { XLI - Prądnik Czerwony, XLII - Olsza, } \\
\text { XXLIII - Rakowice, XLIV - Czyżyny, } \\
\text { XLV - Łęg, XLVI - Rybitwy, } \\
\text { XLVII - Bieżanów, XLVIII - Rżąka, } \\
\text { XLIX - Prokocim, L - Wola Duchacka, } \\
\text { LI - Piaski Wielkie, LII - Kurdwanów }\end{array}$ & $\begin{array}{l}\text { LIII - Mogiła, LIV - Bieńczyce, } \\
\text { LV - Mistrzejowice, LVI - Zesławice, } \\
\text { LVII - Kantorowice, LVIII - Krzesławice, } \\
\text { LIX - Grębałów, LX - Lubocza, } \\
\text { LXI - Wadów, LXII - Pleszów, } \\
\text { LXIII - Ruszcza, LXIV - Branice }\end{array}$ \\
\hline
\end{tabular}

Źródło: opracowanie własne. 
Tabela 4. Nazwy dawnych wsi, jurydyk, folwarków i majątków ziemskich uwidocznione w nazwach osiedli i innych części miasta (nazwy kursywą)

\begin{tabular}{|c|c|c|}
\hline \multicolumn{2}{|r|}{ Rejestr TERYT wg delegatur } & \multirow{3}{*}{$\begin{array}{l}\text { Strukturalne jednostki urbanistyczne } \\
\text { Azory Północ, Bieńczyce, Bodzów-Kostrze, Borek } \\
\text { Fałęcki, Branice-Ruszcza, Bronowice Centrum, Bro- } \\
\text { nowice Małe, Bronowice Wielkie, Cmentarz Rako- } \\
\text { wicki, Czyżyny, Dabie, Débniki, Dolina Dłubni, } \\
\text { Górka Narodowa, Grębałów-Lubocza, Grzegórzki, } \\
\text { Kazimierz-Stradom, Kobierzyn Południe, Kom- } \\
\text { binat Metalurgiczny, Kopiec Krakusa-Bonarka, } \\
\text { Las Wolski, Łagiewniki, Łobzów, Łuczanowice- } \\
\text {-Kościelniki, Małe Błonia, Mistrzejowice, Mydlniki, } \\
\text { Myśliwska-Bagry, Nowe Miasto, Nowy Bieżanów, } \\
\text { Olsza, Olszanica, Opatkowice i Sidzina, Otoczenie } \\
\text { Błoń, Park Nadwiślański Wschód, Park Nadwi- }\end{array}$} \\
\hline Kraków-Krowodrza & $\begin{array}{l}\text { Azory, Bielany, Bronowice Małe, Bronowice Wielkie, } \\
\text { Chetm, Cichy Kącik, Czarna Wieś, Górka Narodowa, } \\
\text { Krowodrza, Las Wolski, Łobzów, Mydlniki, Nowa Wieś, } \\
\text { Olszanica, Półwsie Zwierzynieckie, Pradnik Biały, Prze- } \\
\text { gorzały, Salwator, Stara Krowodrza, Tonie, Witkowice, } \\
\text { Wola Justowska, Zwierzyniec }\end{array}$ & \\
\hline Kraków-Nowa Huta & $\begin{array}{l}\text { Bieńczyce, Branice, Chałupki, Czyżyny, Grębałów, } \\
\text { Kantorowice, Kościelniki, Krzesławice, Lubocza, Łęg, } \\
\text { Łuczanowice, Mistrzejowice, Mogiła, Nowa Huta, Ple- } \\
\text { szów, Przylasek Rusiecki, Przylasek Wyciaski, Ruszcza, } \\
\text { Wadów, Węgrzynowice, Wolica, Wróżenice, Wyciąże, Ze- } \\
\text { sławice }\end{array}$ & \\
\hline Kraków-Podgórze & $\begin{array}{l}\text { Bieżanów, Bodzów, Bonarka, Borek Fałęcki, Cegielniana, } \\
\text { Dębniki, Golikówka, Jugowice, Kliny, Kobierzyn, Kosocice, } \\
\text { Kostrze, Kurdwanów, Ludwinów, Łagiewniki, Opatkowi- } \\
\text { ce, Piaski Wielkie, Płaszów, Podgórze, Prokocim, Przewóz, } \\
\text { Pychowice, Rajsko, Rybitwy, Rżąka, Sidzina, Skotniki, So- } \\
\text { boniowice, Swoszowice, Tyniec, Wola Duchacka, Wróblo- } \\
\text { wice, Zaborze, Zakrzówek, Zbydniowice }\end{array}$ & $\begin{array}{l}\text { łudnie, Pierwsza Obwodnica, Pleszów, Płaszów- } \\
\text {-Rybitwy, Płaszów-Zabłocie, Pradnik Biaty, Prądnik } \\
\text { Czerwony, Prokocim CM, Przylasek Rusiecki-Wolica, } \\
\text { Rejon Dobrego Pasterza, Ruczaj-Kobierzyn, Skot- } \\
\text { niki, Śródmiejski Park Nadwiślany, Stara Nowa } \\
\text { Huta, Stare Czyżyny-Łęg, Stare Miasto, Stare Pod- } \\
\text { górze, Stary Bieżanów, Stary Prokocim, Swoszowice- }\end{array}$ \\
\hline Kraków-Śródmieście & $\begin{array}{l}\text { Dąbie, Grzegórzki, Kazimierz, Kleparz, Nowy Świat, } \\
\text { Olsza, Piasek, Pradnik Czerwony, Rakowice, Stare Mia- } \\
\text { sto, Ugorek, Warszawskie, Wawel, Wesoła, Wieczysta, } \\
\text { Wiśniowa }\end{array}$ & $\begin{array}{l}\text {-Rajsko, Tonie, Tyniec, Ugorek, Wola Duchacka, } \\
\text { Wola Justowska, Zakrzówek-Pychowice }\end{array}$ \\
\hline
\end{tabular}

Źródło: Studium uwarunkowań... (2014), Rejestr TERYT (2020).

- nazwy nawiązujące do dziedzictwa materialnego i niematerialnego, $\mathrm{w}$ tym postaci i wydarzeń uwiecznionych w podaniach, legendach oraz różnorodnych tekstach kultury, tradycji i zwyczajów miejscowych (np. ul. Emaus, ul. Gzymsików, ul. Krowoderskich Zuchów, ul. Kukiełek Golkowickich, ul. Lajkonika);

- nazwy mające związek z wsią i tradycją wiejską w znaczeniu ogólnym (np. ul. Chłopska, ul. Dożynkowa, ul. Rolnicza, ul. Urodzajna, ul. Żyzna).

W obrębie poszczególnych osiedli zastosowano różne rozwiązania nazewnicze, m.in. z wykorzystaniem
Łzw. gniazd nazewniczych. W części osiedli nazwy ulic nawiązują bezpośrednio do tradycji lokalnych i miejscowego krajobrazu. Za przykład może posłużyć m.in. Tyniec (tab. 5). Należy zaznaczyć, że w niektórych przypadkach nazwa ulicy bądź placu jest ostatnim nawiązaniem i jedynym odniesieniem do przeszłości. Przykładowo pl. Błonie-Beszcz to jedyny odnośnik do zanikłej osady Beszcz, a ul. Kapelanka, ul. Gramatykaczy czy też ul. Kawiory nawiązują do nazw folwarków i majątków ziemskich, znanych jedynie z dokumentów archiwalnych.

Tabela 5. Nazwy ulic Tyńca ze względu na pochodzenie

\begin{tabular}{|c|c|}
\hline Rodzaj nazwy & Przykłady ulic \\
\hline Nazwy kierunkowe & ul. Tyniecka (prowadząca od Dębnik do Tyńca) \\
\hline $\begin{array}{l}\text { Nazwy nawiązujące do miejscowej topografii/ } \\
\text { obiektów fizjograficznych }\end{array}$ & $\begin{array}{l}\text { ul. Bagienna, ul. Bogucianka, ul. Bór, ul. Grodzisko, ul. Skołczanka, } \\
\text { ul. Stępica, ul. Świętojańska, ul. Wielogórska, ul. Zagórze, ul. Zakleśnie }\end{array}$ \\
\hline $\begin{array}{l}\text { Nazwy związane ze znaczącym obiektem } \\
\text { architektonicznym (zespół klasztorny) }\end{array}$ & $\begin{array}{l}\text { ul. Benedyktyńska, ul. Bolesława Śmiałego, ul. Browarniana, ul. Obrony } \\
\text { Tyńca, ul. Stanisława Szczygielskiego }\end{array}$ \\
\hline Nazwy związane z postaciami historycznymi & ul. Bolesława Śmiałego, ul. Stanisława Szczygielskiego, ul. Świętojańska \\
\hline Nazwy związane z wydarzeniami historycznymi & ul. Grodzisko, ul. Obrońców Tyńca \\
\hline Nazwy związane z funkcjami gospodarczymi & ul. Browarniana, ul. Dziewiarzy, ul. Promowa \\
\hline Nazwy związane z legendami i podaniami & ul. Heligundy, ul. Walgierza Wdałego, ul. Świętojańska \\
\hline Nazwy związane z literaturą & $\begin{array}{l}\text { ul. Lutego Tura, ul. Juranda ze Spychowa, ul. Danusi Jurandówny, } \\
\text { ul. Maćka z Bogdańca }\end{array}$ \\
\hline
\end{tabular}

Źródło: opracowanie własne. 
Ciekawym zagadnieniem jest również sposób nazywania przystanków komunikacji miejskiej. Z jednej strony ich nazwy reprezentują znacznie większy wachlarz miejskiej toponimii, w dużej mierze ułatwiając orientację w przestrzeni miasta mieszkańcom i przyjezdnym, z drugiej jednak strony stałe zmiany nazewnictwa idace $w$ kierunku dostosowywania do nazw ulic lub obiektów użyteczności publicznej powoduje, że z krajobrazu miasta znikają stopniowo utrwalone przez pokolenia nazwy.

Nazwy dawnych wsi przeszły nie tylko do toponimii miasta, ale także znalazły szersze zastosowanie. Dla przykładu nazwa „Łobzów” na mapie współczesnego Krakowa uwidacznia się m.in. jako:

- ul. Łobzowska (ulica wiodąca z centrum Krakowa w kierunku Łobzowa);

- Łobzów jako nazwa dawnej dzielnicy (można jeszcze spotkać na domach tabliczki z taką nazwą dzielnicy) (fot. 2);

- Łobzów jako strukturalna jednostka urbanistyczna;

- umiejscowienie dawnego zamku - rezydencji królewskiej na Łobzowie;

- ul. Jadwigi z Łobzowa (nazwa wtórna);

- Spółdzielnia Mieszkaniowa „Łobzów”;

- Ogród „Łobzów” - przykład chrematonimu odnoszącego się do dziedzictwa kulturowego miejsca.

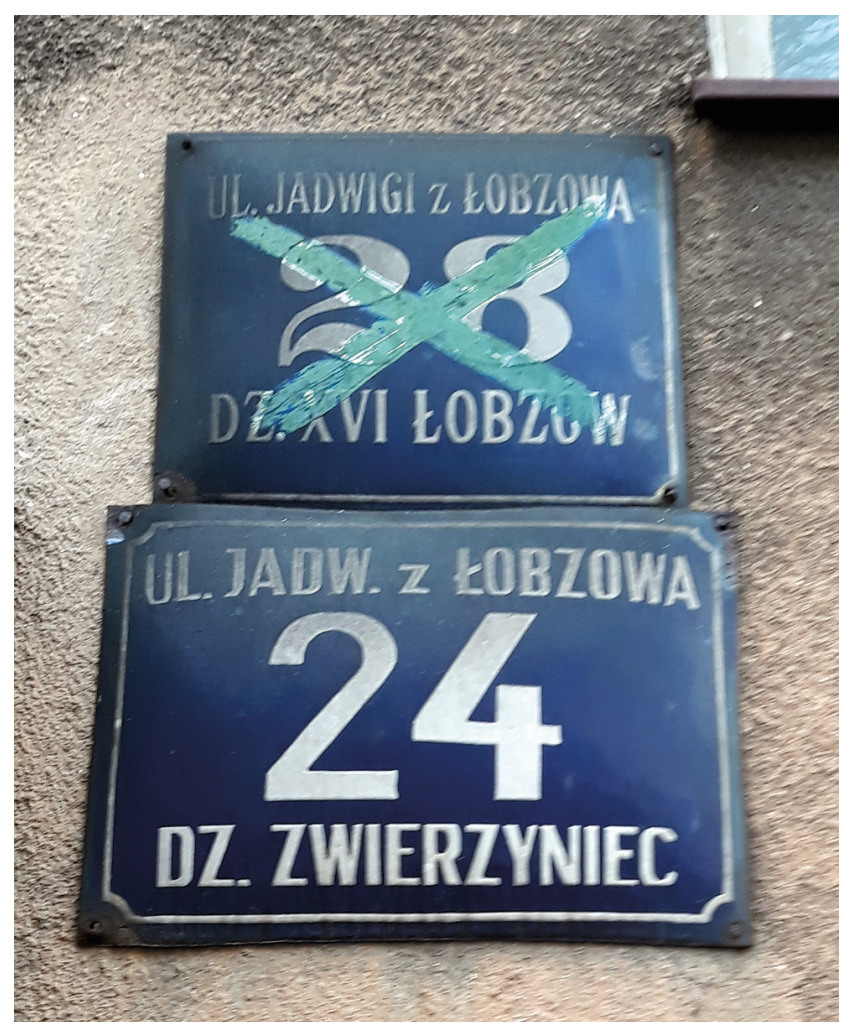

Fotografia 2. Tabliczki z numeracją domu przy ul. Jadwigi z Łobzowa.

Aktualnie cała ulica

znajduje się w obrębie dzielnicy VI Bronowice Źródło: R. Faracik (10.01.2020)

\section{ROLNICTWO W KRAKOWIE W KONTEKŚCIE SPUŚCIZNY KULTUROWEJ DAWNYCH WSI}

Rolnictwo pełni podstawową funkcję gospodarczą obszarów wiejskich, dlatego też stan jego rozwoju może wskazywać na cechy „wiejskości” danego obszaru. Kraków wyraźnie wyróżnia się spośród dużych miast w Polsce ze względu na znaczący odsetek użytków rolnych w całkowitej powierzchni miasta, który współcześnie wynosi ok. 40\%. Z danych z ewidencji gruntów wynika jednak, że wartość ta stale spada, co wiąże się z powszechnie obserwowanymi tendencjami do wyłączania z produkcji rolnej („odrolnienia”) gruntów rolnych, zwłaszcza w obrębie aglomeracji miejskich, i przeznaczania ich pod budownictwo mieszkaniowe i usługi (Kowalewski i in. 2014; Śleszyński, Komornicki, Deręgowska, Zielińska, 2014).

W 2005 r. ogólna powierzchnia użytków rolnych w Krakowie wynosiła 16,7 tys. ha, co stanowiło $51,2 \%$ powierzchni całego miasta. W 2017 r. ${ }^{5}$ wartości te wynosiły odpowiednio 14,6 tys. ha i 44,5\%. Wśród użytków rolnych grunty orne, sady, łąki i pastwiska trwałe stanowiły 93,6\% w 2005 r. i 96,2\% w 2017 r. (tab. 6). Według analiz Luchtera $(2009,2010)$ maksymalny udział użytków rolnych w ogólnej powierzchni miasta miał miejsce w 1900 r. (89\%), od tego czasu notuje się stały spadek omawianego wskaźnika, przy czym największa dynamika spadku przypada na lata 50. XX w. (budowa kombinatu metalurgicznego i rozbudowa tkanki urbanistycznej Nowej Huty). Udział gruntów ornych w ogólnej powierzchni użytków rolnych w latach 18482008 kształtował się na mniej więcej stałym poziomie (69\%). Spadek areału użytków rolnych odnotowują też w swoich pracach Krzyk (2009), Krzyk, Bury (2013) oraz Krzyk, Tokarczuk, Heczko-Hyłowa, Ziobrowski (2013).

Dokładniejszych danych dostarczają wyniki spisu rolnego ${ }^{6}$. Z ogólnodostępnych danych z 2002 r. wynika, że w granicach administracyjnych Krakowa

Tabela 6. Powierzchnia użytków rolnych w Krakowie w latach 2005-2017 (ha)

\begin{tabular}{|l|c|c|c|}
\hline \multirow{2}{*}{ Rok } & \multicolumn{2}{|c|}{ Użytki rolne } & \multirow{2}{*}{$\begin{array}{c}\text { Grunty rolne } \\
\text { zabudowane }\end{array}$} \\
\cline { 2 - 3 } & ogółem & $\begin{array}{c}\text { w tym: grunty orne, sady, } \\
\text { łąki i pastwiska trwałe }\end{array}$ & 1516 \\
\hline 2005 & 16739 & 15662 & 1521 \\
\hline 2007 & 16386 & 15454 & 1533 \\
\hline 2009 & 16205 & 15299 & 1729 \\
\hline 2011 & 15758 & 14930 & 1731 \\
\hline 2013 & 15369 & 14608 & 1745 \\
\hline 2015 & 14976 & 14608 & - \\
\hline 2017 & 14559 & 14007 & \\
\hline
\end{tabular}

Źródło: Rocznik statystyczny Krakowa (2005, 2007, 2009, 2011, 2013, 2015, 2017). 
powierzchnia wszystkich gospodarstw wynosiła $10,5$ tys. ha, z czego 8,7 tys. ha ( $83,4 \%)$ stanowiły użytki rolne. Grunty orne obejmowały 6,9 tys. ha $(65,9 \%)$ ogólnej powierzchni gospodarstw rolnych $(1,8$ tys. ha odłogowanych i 0,4 tys. ha ugorowanych). Poza tym było 225 ha sadów, około 1300 ha łąk i nieco ponad 300 ha pastwisk. Spis wykazał funkcjonowanie 6332 gospodarstw rolnych, z czego 6323 były gospodarstwami indywidualnymi. Około $68 \%$ wszystkich gospodarstw miało powierzchnię mniejszą niż 1 ha. W powierzchni zasiewów dominowały zboża (2,5 tys. ha $-53,3 \%)$ oraz ziemniaki. Pogłowie zwierząt obejmowało m.in. 1,3 tys. sztuk bydła i 2,8 tys. sztuk trzody chlewnej. Duże powierzchnie zajmują także uprawy warzyw, w tym pod osłonami. Szczególna rola przypada pszczelarstwu, które w swojej „miejskiej” odsłonie stało się bardzo popularne w ostatnich latach. Oprócz indywidualnych pasiek $^{7}$, na uwagę zasługuje projekt „Pasieka Kraków” organizowany i wspóffinansowany przez Gminę Miejską Kraków (obecnie jest to 9 pasiek, z których 7 usytuowanych jest na dachach budynków, a 2 mają charakter naziemny).

Większość użytków rolnych, w tym gruntów ornych, zlokalizowana jest $\mathrm{w}$ dzielnicach peryferyjnych, przy czym najbardziej rozwinięta rolniczo jest Dzielnica XVIII Nowa Huta, a zwłaszcza północne i wschodnie otoczenie kombinatu metalurgicznego (rys. 4). Poza tym, ze względu na walory glebowe, predystynowane do funkcji rolniczej są także części dzielnic: IV Prądnik Biały, VI Bronowice, VII Krowodrza, XV Mistrzejowice oraz XVII Wzgórza Krzesławickie (Skiba, Drewnik, 2010). W wielu przypadkach funkcja rolnicza dominuje w krajobrazie tych osiedli (np.: Łuczanowice, Kościelniki, Wadów, Wyciąże, Wolica, Przylasek Rusiecki), co wiąże się z bardzo dobrymi warunkami przyrodniczymi (zwłaszcza żyznymi glebami) oraz tradycjami w tej dziedzinie (rys. 4). Należy zaznaczyć, że przed budową kombinatu na obszarze Nowej Huty (w granicach dzielnicy sprzed $1991 \mathrm{r}$.) udział gruntów rolnych $\mathrm{w}$ jej ogólnej powierzchni wynosił 91,7\%, a w 2010 r. 51,7\%, zaś grunty orne stanowiły odpowiednio 70,6\% i 39,0\% (Luchter, 2011).

Tradycje rolnicze uwidaczniają się m.in. w dożynkach, przybierających formę „święta plonów" (Cieśla-Reinfussowa, 1977). Od 2004 r. organizowane są Dożynki Miejskie (wcześniej nazywane Dożynkami Krakowskimi). Odbywają się one co roku w różnych częściach miasta (osiedlach), w których wciąż żywe są tradycje rolnicze. Dodatkowo organizowane są dożynki dzielnicowe, a najdłuższą tradycję mają te odbywające się w Nowej Hucie. Lokalne obchody realizowane są także w obrębie samych osiedli, a organizują je miejscowe instytucje społeczne i religijne (przykładem mogą być Dożynki Witkowickie) (tab. 7, rys. 5).

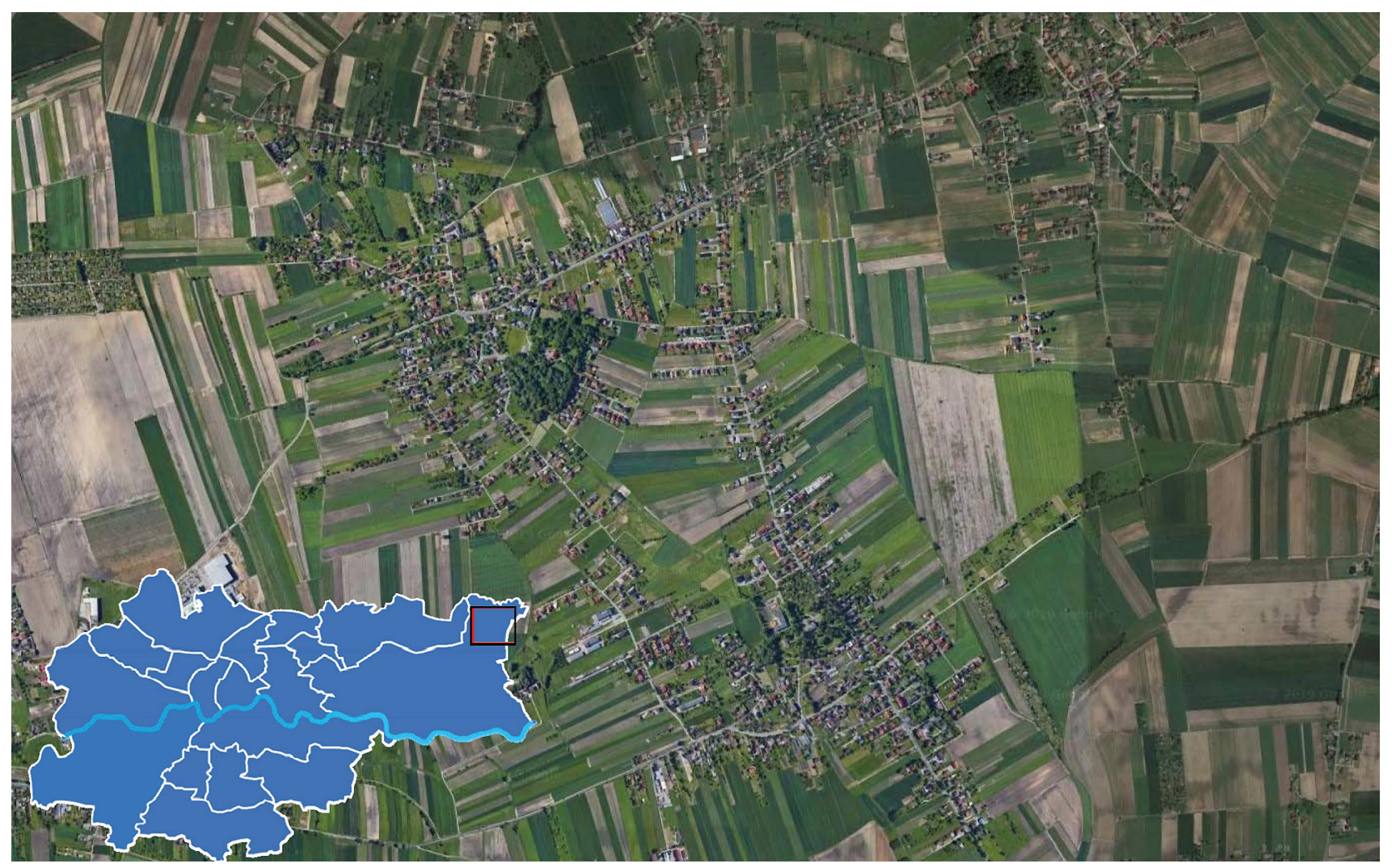

Rysunek 4. Łuczanowice i Wadów z zachowanym rozłogiem pól wykorzystywanych rolniczo Źródło: opracowanie własne na podstawie zasobów Google Maps (2019) 
Tabela 7. Lokalizacja dożynek miejskich i dzielnicowych w latach 2004-2019

\begin{tabular}{|c|c|c|c|}
\hline Część miasta (osiedle) & Dożynki miejskie & Dożynki dzielnicowe & Uwagi \\
\hline Branice & - & 2007,2014 & Dzielnica Nowa Huta \\
\hline Chałupki & - & 2011 & Dzielnica Nowa Huta \\
\hline Czyżyny & 2017 & - & - \\
\hline Kantorowice & 2012 & - & - \\
\hline Kościelniki & - & 2010,2016 & Dzielnica Nowa Huta \\
\hline Lubocza & - & 2013 & Dzielnica Nowa Huta \\
\hline Łęg & 2014 & 2019 & Dzielnica Czyżyny \\
\hline Łuczanowice & 2008 & - & - \\
\hline Mogiła & 2004,2005 & - & jako Dożynki Krakowskie \\
\hline Olszanica & 2010 & - & - \\
\hline Pleszów & - & 2017 & Dzielnica Nowa Huta \\
\hline Płaszów & - & 2013 & Dzielnica Podgórze \\
\hline Półwsie Zwierzynieckie & 2019 & - & na Błoniach \\
\hline Prądnik Biały & 2009 & - & - \\
\hline Przewóz & 2018 & 2011,2016 & Dzielnica Podgórze \\
\hline Przylasek Rusiecki & - & 2015 & Dzielnica Nowa Huta \\
\hline Ruszcza & - & 2012 & Dzielnica Nowa Huta \\
\hline Rybitwy & - & 2015, 2017, 2019 & Dzielnica Podgórze \\
\hline Sidzina & 2006,2011 & - & - \\
\hline Skotniki & 2016 & - & - \\
\hline Swoszowice & 2015 & - & - \\
\hline Wadów & - & 2011 & Dzielnica Wzgórza Krzesławickie \\
\hline Wolica & 2013 & 2008 & Dzielnica Nowa Huta \\
\hline Wróblowice & 2007 & - & - \\
\hline Wróżenice & - & 2009,2019 & Dzielnica Nowa Huta \\
\hline Wyciąże & - & 2018 & Dzielnica Nowa Huta \\
\hline
\end{tabular}

Źródło: opracowanie własne.

Na odrębność „wiejskich” i rolniczych obszarów w obrębie Krakowa w 2012 r. zwróciła uwagę grupa krakowskich radnych, która zaproponowała ustanowienie 17 sołectw z sołtysami na ich czele, co pozwoliłoby

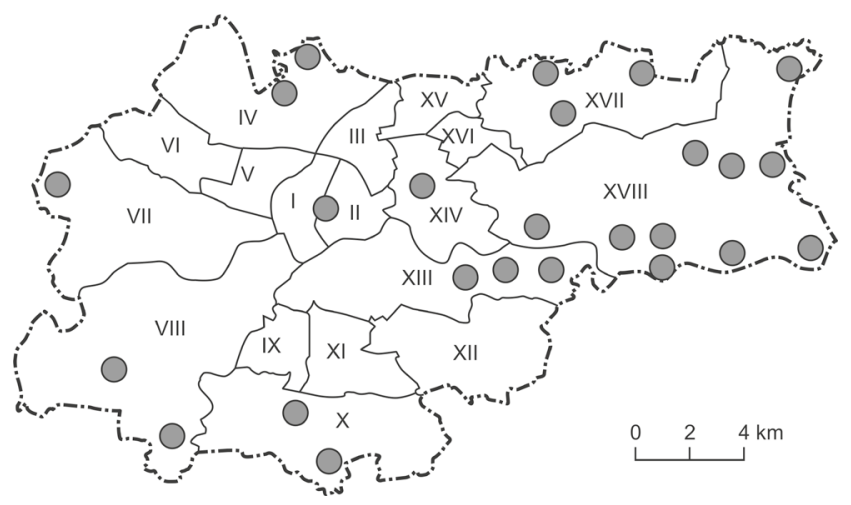

Rysunek 5. Lokalizacja imprez dożynkowych w latach 2004-2019 Źródło: opracowanie własne na pozyskiwanie dodatkowych środków z rządowego Programu Rozwoju Obszarów Wiejskich. Wnioskodawcy uzasadniali ten pomysł m.in. odrębnością od miejskiego układu urbanistycznego i charakterem wspólnot lokalnych, różnych od zbiorowości miejskiej. Jednym z głównych kryteriów przyjętych przy delimitacji proponowanych sołectw był udział użytków rolnych i liczba mieszkańców zatrudnionych w rolnictwie. Proponowane sołectwa to: Bronowice Wielkie i Tonie w dzielnicy IV Prądnik Biały; Mydlniki w dzielnicy VI Bronowice; Kostrze-Bodzów, Sidzina-Olszyny i Tyniec w dzielnicy VIII Dębniki; Bielany i Olszanica w dzielnicy VII Zwierzyniec; Rajsko-Soboniowice-Kosocice, Wróblowice-Zbydniowice i Opatkowice w dzielnicy X Swoszowice; Przewóz w dzielnicy XIII Podgórze; Zesławice-Kantorowice w dzielnicy XVII Wzgórza Krzesławickie; Węgrzynowice-Kościelniki, Wyciąże-Przylasek Rusiecki i Branice w dzielnicy XVIII Nowa Huta (rys. 6). 


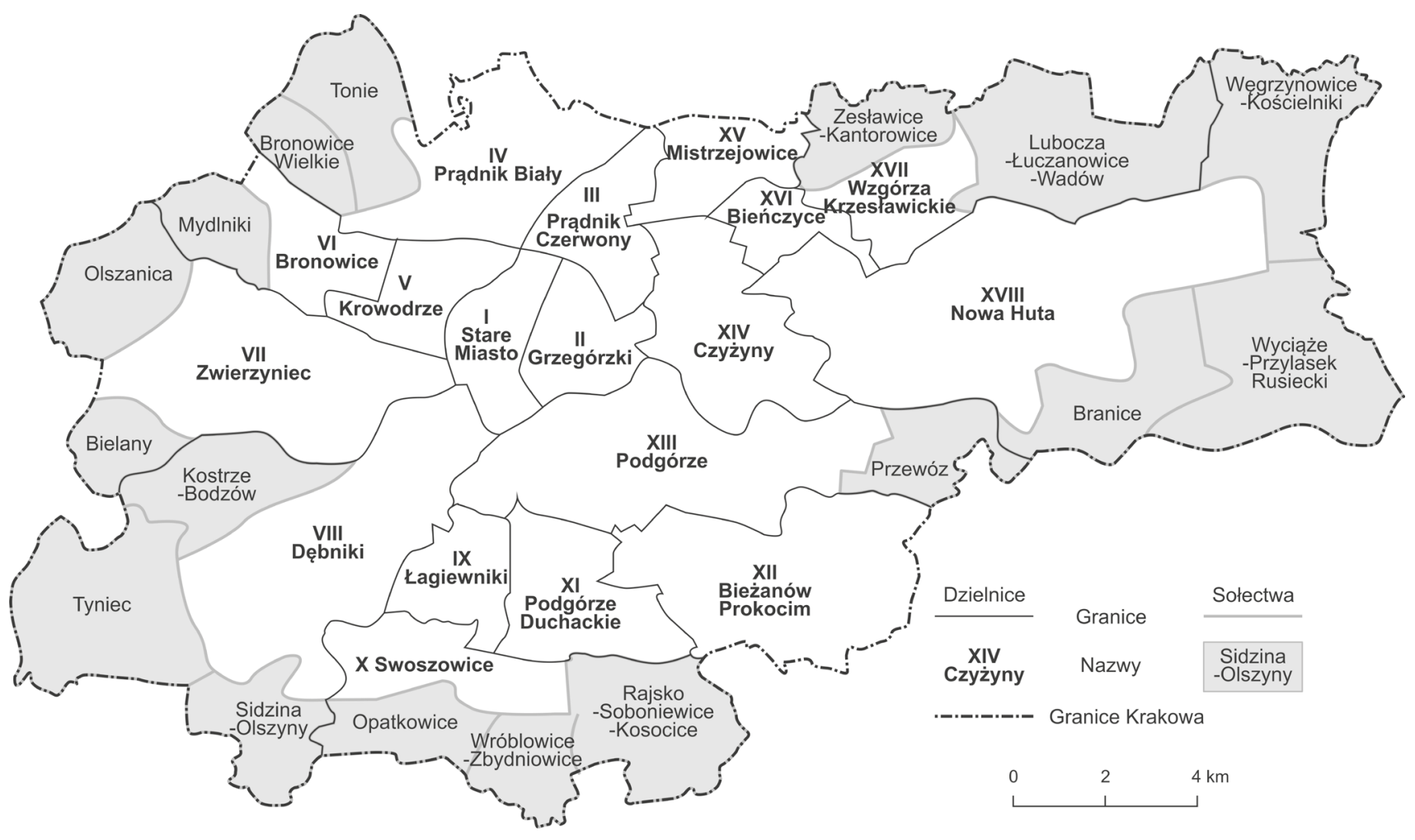

Rysunek 6. Proponowane w 2012 r. sołectwa w obrębie miasta Krakowa Źródło: Kraków Naszemiasto.pl (2020)

\section{KULTURA LUDOWA \\ I JEJ REMINISCENCJE W KRAJOBRAZIE KULTUROWYM MIASTA}

Ważnym elementem życia społecznego wsi było kultywowanie zwyczajów, tradycji i obrzędów związanych zarówno z kalendarzem prac polowych i świąt religijnych, jak i wydarzeniami rodzinnymi i osobistymi. Unikatową wartość mają także w wielu przypadkach wyroby lokalnego rękodzieła. Świadczy to o specyficznej kulturze społeczności wiejskiej, która zaczęła się kształtować w niższych warstwach społecznych już we wczesnym średniowieczu, a nazywana jest często kulturą ludową. Ważną cechą tego zjawiska jest izolacjonizm, który wyraźnie odróżnia kulturę ludową od elitarnej. Regionalne zróżnicowanie obyczajów wynika z braku lub ograniczonego kontaktu z innymi społecznościami lokalnymi, przez co kultura ludowa wyróżnia się swoistą specyfiką miejscowych warunków ją kształtujących (Bukraba-Rylska, 1998; Encyklopedia PWN, 2020).

Tradycje chłopskie oraz kultura ludowa Krakowiaków wyróżniają Kraków spośród innych dużych miast w Polsce (Cieśla-Reinfussowa, 1977). Strój ludowy Krakowiaków Zachodnich (tzw. strój bronowicki) wraz ze strojem łowickim stały się znakami rozpoznawczymi polskiej kultury ludowej, swoistymi symbolami polskości i „polskimi strojami narodowymi”. Strój krakowski należy do najbardziej rozpoznawalnych spośród polskich strojów ludowych, a krakowiak nauczany jest od najmłodszych etapów edukacji zarówno w formie piosenek, jak i tańców. Należy zaznaczyć, że rola i znaczenie kultury ludowej Krakowiaków w dużej mierze jest owocem znaczenia miasta i regionu w procesie obrony polskości w okresie zaborów oraz walki o wolność i samostanowienie, a tradycje chłopskie w tym względzie (np. udział w powstaniach narodowych, zwłaszcza w insurekcji kościuszkowskiej) należą do najbardziej znanych i utrwalonych w różnych tekstach kultury (m.in. literatura, malarstwo, muzyka) oraz w treściach nauczania na różnych poziomach edukacji szkolnej.

Współczesny folkloryzm nawiązuje do tych tradycji na różnych poziomach życia społecznego i kulturalnego. Elementy stroju krakowskiego widoczne są w mieście wśród ulicznych grajków przygrywających turystom, w sklepach z pamiątkami i wyrobami rękodzieła ludowego, w salach koncertowych i widowiskowych lub podczas różnego rodzaju imprez o charakterze historycznym, kulturalnym, społecznym, gospodarczym czy politycznym.

Część zwyczajów rodem z dawnych podkrakowskich wsi współcześnie należy do kanonu krakowskich wydarzeń kulturalnych, a nawet stała się swoistym symbolem miasta. Przykładem może być m.in. Lajkonik - Konik Zwierzyniecki, którego depozytariuszkami były norbertanki zwierzynieckie. Pierwotnie pochód konika wiązał się z obrzędami religijnymi (oktawa 
Bożego Ciała), a jego sprawowanie należało do kongregacji włóczków (flisaków) z Półwsia Zwierzynieckiego. W XIX w., wraz z upływem czasu, obrzęd ten stopniowo zatracał swoje pierwotne znaczenie, stając się w konsekwencji ludową zabawą. Współcześnie pochód Lajkonika (tzw. harce) w towarzystwie kapeli „Mlaskotów" i orszaku włóczków przyciągają rzesze mieszkańców i przyjezdnych w oktawę Bożego Ciała, czyli w pierwszy czwartek po Uroczystości Najświętszego Ciała i Krwi Chrystusa (Kwiecińska, 2014b; Szoka, 2014).

Spośród innych wydarzeń o ludowych korzeniach, które wrosły w kulturowy krajobraz dzisiejszego miasta wymienić należy także Emaus i Rękawkę. Emaus to nazwa zwyczaju ludowego, przybierającego formę kiermaszu odpustowego, który od XIX w. odbywa się w poniedziałek wielkanocny przy klasztorze Sióstr Norbertanek na Zwierzyńcu. Spacer wzdłuż kramów i zabawy odpustowe stały się ważnym wydarzeniem, w którym udział brali mieszkańcy Krakowa. Jest to jedna z najstarszych tego typu imprez w Europie Środkowej, a jej tradycje kultywowane są do dzisiaj (Kwiecińska, 2014a). Rękawka to zwyczaj praktykowany we wtorek po świętach wielkanocnych, mający swoje początki jeszcze w czasach pogańskich i nawiązujący do tradycji starosłowiańskiej. Obecnie jest to impreza plenerowa $\mathrm{w}$ formie festynu, odbywająca się na Krzemionkach Podgórskich na Wzgórzu Lasoty, w sąsiedztwie kościółka św. Benedykta oraz wokół Kopca Krakusa (Oleszkiewicz, 2016).

Z dawnych podkrakowskich wsi (m.in. Krowodrza, Zwierzyńca, Czarnej Wsi, Grzegórzki, Ludwinowa), które w XIX w. stały się przedmieściami Krakowa, wywodzi się inny symbol współczesnego miasta - szopka krakowska. Twórcami szopek pierwotnie byli murarze i inni pracownicy budowlani pochodzący ze wspomnianych wsi, którzy, wykorzystując przerwę zimową w pracach budowlanych, zajęli się wytwarzaniem specyficznych szopek, swoją formą nawiązujących do przykładów budownictwa i architektury krakowskiej. Coroczny konkurs szopek krakowskich, a następnie ich wystawa wpisały się na trwałe do kalendarza imprez kulturalnych miasta (Kozieł, 2003; Kwiecińska, 2017; Szałapak, 2012).

Inną formą rękodzieła o ludowych korzeniach jest krakowskie koronkarstwo klockowe ${ }^{8}$, które obecnie praktykowane jest przez zaledwie około 30 koronczarek z Krakowa i okolic. Tradycje te kultywowane są m.in. w ramach Warsztatów Rękodzieła Artystycznego „Czar nici”, których początki sięgają 1999 r. (Czar nici, 2020). W Krakowie pracują także twórcy z zakresu: bibułkarstwa, plecionkarstwa, wycinankarstwa oraz różnych form plastyki obrzędowej związanych m.in. z rocznym kalendarzem obrzędowym (np. wieńce dożynkowe).

W ciągu roku w Krakowie organizowane są różne imprezy kulturalne, łączące się bezpośrednio $\mathrm{z}$ folklorem i szeroko rozumianą kulturą ludową. Do imprez o najdłuższej tradycji należą Międzynarodowe Targi Sztuki Ludowej, ich 44 odsłona miała miejsce na Rynku Głównym w 2020 r. Spośród innych imprez wymienić można Kiermasz Pogranicze Kultur, który po raz 16 odbył się w 2020 r. Do lokalnych tradycji nawiązują także opisane wcześniej dożynki, obchodzone na różnych szczeblach: osiedlowym, dzielnicowym czy miejskim. Długą historię ma także święto pszczelarzy, Krakowskie Miodobranie, tradycyjnie organizowane we wrześniu na Placu Wolnica.

Do tradycji ludowych nawiązuje działalność zespołów pieśni i tańca, które w swoim repertuarze odnoszą się zarówno do folkloru Krakowiaków, jak i innych grup etnograficznych w Polce i Europie. Są to:

- Ośrodek Kultury Krakowiacy - Zespół Pieśni i Tańca „Krakowiacy" (miejska jednostka organizacyjna - instytucja kultury);

- Międzyszkolny Ludowy Zespół Pieśni i Tańca „Krakowiak" (miejska jednostka organizacyjna - młodzieżowy dom kultury);

- Zespół Pieśni i Tańca „Małe Słowianki” (w ramach Centrum Młodzieży w Krakowie jako miejskiej jednostki organizacyjnej - młodzieżowego domu kultury);

- Zespół Pieśni i Tańca „Nowa Huta” (w ramach Nowohuckiego Centrum Kultury jako miejskiej jednostki kultury);

- Zespół Pieśni i Tańca Akademii Górniczo-Hutniczej „Krakus" im. Wiesława Białowąsa;

- Zespół Pieśni i Tańca Uniwersytetu Jagiellońskiego "Słowianki".

Niezwykle ważną rolę w kultywowaniu wiedzy o kulturze ludowej oraz zachowaniu i popularyzacji tradycji odgrywa otwarte w 1911 r. Muzeum Etnograficzne w Krakowie im. Seweryna Udzieli. Instytucja ta prowadzi działalność wystawiennicza, naukowa i edukacyjną z zakresu szeroko rozumianej etnologii w ujęciu historycznym i współczesnym. Także Muzeum Historyczne Miasta Krakowa ${ }^{9}$ prowadzi działalność wystawiennicza, edukacyjna, naukową i konserwatorską w zakresie tradycji lokalnych i folkloru miejskiego.

Oddzielnym zagadnieniem jest kwestia wykorzystania kultury ludowej i jej obecności $w$ różnego rodzaju nurtach sztuk plastycznych, w literaturze czy muzyce. Pod tym kątem szczególne znaczenie ma ruch artystyczny Młodej Polski, którego centrum stanowił właśnie Kraków. Wiele dzieł sztuki z tego okresu do dzisiaj można podziwiać w różnych miejscach w Krakowie - w muzeach, budynkach użyteczności publicznej oraz domach i mieszkaniach prywatnych ${ }^{10}$. Najbardziej znaną postacia, szczególnie związaną z Krakowem, jest Stanisław Wyspiański. Jego dzieła malarskie, witraże oraz literatura należą do kanonu sztuki młodopolskiej. Jego dramaty symboliczne, a zwłaszcza "Wesele", mają nie tylko znaczenie literackie, ale wpływają też na inne dziedziny sztuki. W miejscu akcji „Wesela”, 
a więc w dworku wybudowanym przez Włodzimierza Tetmajera w Bronowicach Małych nazwanym później „Rydlówką”, mieści się od 1969 r. Muzeum Młodej Polski, które od 2018 r. stanowi oddział Muzeum Krakowa (wcześniej administrowane przez PTTK). Rokrocznie, około 20 listopada, na pamiątkę słynnego wesela Rydlów odbywa się przed dworkiem symboliczne „osadzanie chochoła”, czyli uroczyste okrywanie krzaku róży słomianą otuliną. Wydarzeniu temu towarzyszy symboliczny taniec w strojach ludowych wokół chochoła oraz występy krakowskich artystów. Dzięki Wyspiańskiemu Bronowice zaistniały w polskiej literaturze, ale też wraz ze swoim szeroko rozumianym „krajobrazem” stały się jednym z wyznaczników polskiej kultury (Radecka, 2016; Waltoś, 2000).

\section{PODSUMOWANIE}

Stopień zachowania i reprezentacji różnych aspektów wiejskości w krajobrazie kulturowym miasta jest kwestią ściśle powiązaną z indywidualnymi cechami danego ośrodka: warunkami środowiska przyrodniczego, historia, strukturą demograficzną i społeczna, tradycjami, polityką czy też więziami społecznymi i gospodarczymi łączącymi go z innymi jednostkami tak w układzie lokalnym i regionalnym, jak i ogólnokrajowym. Dlatego też badanie tego zjawiska ma charakter inter- i transdyscyplinarny, a zaangażowanych jest w nie szereg dyscyplin naukowych, reprezentujących różne dziedziny nauki. Należy wspomnieć w tym kontekście m.in.: nauki o Ziemi i środowisku, geografię społeczno-ekonomiczną i gospodarkę przestrzenną, ekonomię i finanse, etnografię (etnologię), nauki socjologiczne, politologię, historię, filozofię, psychologię, religioznawstwo, językoznawstwo, literaturoznawstwo, nauki o kulturze i religii, architekturę i urbanistykę czy też rolnictwo i ogrodnictwo oraz dyscypliny z dziedziny sztuki ${ }^{11}$.

W pracy analizie podano tylko cztery główne aspekty wiejskości, ujawniające się we współczesnym krajobrazie miasta. Całościowe podejście do tego zagadnienia wymaga zaangażowania wymienionych wcześniej różnych dyscyplin w ujęciu wielowymiarowym. Omawiane zjawisko oprócz charakteru endogenicznego, wynikającego bezpośrednio z elementów wiejskości jako pochodnych zjawisk zachodzących w obrębie samego miasta, może być także rozpatrywane w kontekście cech egzogenicznych, będących wynikiem funkcji i znaczenia miasta w odniesieniu do różnych skali przestrzennych.

Mimo że w pracy analizie poddano tylko cztery aspekty związane z wiejskościa, można stwierdzić, że Kraków jest miastem o bogatej spuściźnie po wsiach, których tradycje nadal stanowią ważny element kra- jobrazu kulturowego miasta. Należy zadać sobie pytanie, czy poszczególne wskazane cechy są istotne z punktu widzenia współczesnego miasta i aktualnie zachodzących w nim procesów? Oczywiście odpowiedź nie jest jednoznaczna i prosta, ale wiele wskazuje, że przyjęty kilkadziesiąt lat temu paradygmat nowoczesnego miasta nie przyniósł w pełni oczekiwanych korzyści. Zmiany następujące w sposobie myślenia o współczesnym mieście i procesach w nim zachodzących powodują w wielu przypadkach powrót do rozwiązań tradycyjnych, niejednokrotnie wprost odwołujących się do tradycji wsi jako pierwotnej jednostki organizacji osadnictwa ludzkiego.

Mieszkańcy dużych miast coraz częściej poszukują tradycyjnych rozwiązań na bolączki życia miejskiego. Uwidacznia się to m.in. w aspektach estetycznych (np. zieleń, kwietne łąki w parkach i na skwerach przypominające wiejskie pola, ogrody i skwery obsadzone roślinami kwitnącymi), społecznych (przeciwdziałanie anonimowości, tworzenie miejsc spotkań, różnych pól współpracy sąsiedzkiej, utożsamianie się z miejscem), gospodarczych (rolnictwo miejskie) czy ekologicznych (np. obsiewanie skwerów roślinami miododajnymi, pszczelarstwo miejskie). Nurt ekologiczny stopniowo wpływa na decyzje mieszkańców w zakresie zaopatrzenia w produkty spożywcze - kupowanie tych, które produkowane są na miejscu lub w bezpośrednim sąsiedztwie, a unikanie tych przywożonych z daleka (ślad węglowy). W przypadku Krakowa ważną kwestią jest utrzymanie funkcji rolniczej w celu zachowania bioróżnorodności oraz walorów krajobrazowych, co wiąże się m.in. z objęciem znacznych terenów obszarowymi formami ochrony przyrody (parki krajobrazowe, użytki ekologiczne).

Tradycyjne formy wiejskości, genetycznie związane $\mathrm{z}$ danym miastem, stają się stopniowo elementem współczesnych trendów społecznych i kulturowych, które stanowią próbę odpowiedzi na wyzwania stawiane współczesnym miastom. Jak zaznaczono wcześniej ważną kwestią są aspekty ekologiczne. Zdaniem autora rysuje się wyraźna potrzeba interdyscyplinarnego spojrzenia na tą problematykę tak w odniesieniu do poszczególnych ośrodków miejskich, jak i miast w ogóle. Wielowymiarowość zjawiska wiejskości nie pozwala na pełne ujęcie go tylko z punktu widzenia określonej dyscypliny naukowej i przypisanego do niej aparatu pojęciowego i metodologicznego.

\section{PRZYPISY}

\footnotetext{
${ }^{1}$ W odróżnieniu od wsi i obszarów wiejskich.

${ }^{2}$ Austriackie mapy katastralne znajdujące się w Zintegrowanym Systemie Informacji Archiwalnej ZoSIA dostępne w serwisie Szukaj w Archiwach (2020).

${ }^{3}$ Archiwalne austriackie mapy topograficzne dostępne w serwisie MAPSTER (2020). Mapy aktualne i ortofotomapy dostępne
} 
w serwisach: Małopolska Infrastruktura Informacji Przestrzennej (MIIP) (2020) oraz Geopartal krajowy (2020).

${ }^{4}$ Przykładem może być czeska Praga, gdzie w granicach metropolii znajduje się siedem chronionych zabytkowych stref wiejskich (Vesnická památková zóna) chronionych prawem (Budánka, Stará Hostivař, Královice, Rybáře, Střešovičky, Staré Bohnice, Staré Ď́blice).

${ }^{5}$ Rocznik statystyczny Krakowa ukazuje się co dwa lata, w 2019 r. opublikowano ostatnie dane.

${ }^{6}$ Zbiorcze dane ze spisu rolnego w 2010 r. opublikowano z podziałem według siedziby użytkownika, a nie siedziby gospodarstwa rolnego, co powoduje, że dane dla Krakowa są zawyżone. W chwili opracowywania niniejszego tekstu nie były jeszcze znane końcowe wyniki spisu rolnego z 2020 r.

${ }^{7}$ W Krakowie zarejestrowanych jest około 300 pszczelarzy, z których część prowadzi swoje pasieki na obszarze miasta.

${ }^{8}$ Należy zaznaczyć, że szopkarstwo krakowskie, pochód Lajkonika oraz krakowska koronka klockowa zostały wpisane na "Krajową listę niematerialnego dziedzictwa kulturowego". W 2018 r. szopkarstwo krakowskie zostało wpisane na „Listę reprezentatywną niematerialnego dziedzictwa kulturowego ludzkości UNESCO".

${ }^{9}$ Od 2019 r. działa pod skróconą nazwą Muzeum Krakowa.

${ }^{10} \mathrm{~W}$ Krakowie istnieją trasy turystyczne prowadzące szlakiem Młodej Polski. Wydanych zostało także kilka przewodników po mieście trasą młodopolską oraz śladami znanych twórców tego nurtu, zwłaszcza Stanisława Wyspiańskiego (m.in. Sobieska, Sobieska, Blondiau, 2003; Zbijewska, 1986). Szereg publikacji wydano w 2019 r. w związku z obchodami 150. Rocznicy urodzin Stanisława Wyspiańskiego.

${ }^{11}$ Według klasyfikacji dziedzin i dyscyplin naukowych obowiązujących w Polsce od 2018 r.

\section{BIBLIOGRAFIA}

Bański, J. (2006). Geografia polskiej wsi. Warszawa: Polskie Wydawnictwo Ekonomiczne.

Bański, J. (2007). Geografia rolnictwa Polski. Warszawa: Polskie Wydawnictwo Ekonomiczne.

Bański, J. (2008). Strefa podmiejska - już nie miasto, jeszcze nie wieś. W: A. Jezierska-Thole, L. Kozłowski (red.), Gospodarka przestrzenna w strefie kontinuum miejsko-wiejskiego w Polsce (s. 29-44). Toruń: Instytut Geografii i Przestrzennego Zagospodarowania PAN.

Bański, J. (2012). Problematyka definicji i zasięgu przestrzennego obszarów wiejskich i stref podmiejskich. Acta Scientiarum Polonorum, Administratio Locorum, 11 (3), 5-15.

Bański, J. (2017). Rozwój obszarów wiejskich: wybrane zagadnienia. Warszawa: Polskie Wydawnictwo Ekonomiczne.

Bogdanowski, J. (1996). Kompozycja i planowanie w architekturze krajobrazu. Wrocław: Zakład Narodowy im. Ossolińskich.

Bogdanowski, J. (2001). Czytanie krajobrazu. W: A. Michałowski (red.), Krajobraz kulturowy. Warsztaty dla nauczycieli i metodyków. Zeszyt dydaktyczny (s. 17-33). Warszawa: Ośrodek Ochrony Zabytkowego Krajobrazu.

Bukraba-Rylska, I. (1998). Kultura ludowa. W: A. Woś (red.), Encyklopedia agrobiznesu (s. 454-460). Warszawa: Fundacja Innowacja, Wyższa Szkoła Społeczno-Ekonomiczna.

Cepil, M. (2018). Geneza i dziedzictwo kulturowe osad fryderycjańskich we współczesnych granicach Łodzi. Piotrkowskie Zeszyty Historyczne, 19 (1), 49-66.

Chachaj, J. (2014). Trwałość dawnych elementów krajobrazu i sieci drożnej w ramach współczesnej przestrzeni miejskiej na przykładzie ulic Krańcowej i Wilczej w Lublinie. Studia Geohistorica, 2, 107-117.

Cieśla-Reinfussowa, Z. (1977). Żywotność obrzędów ludowych w Krakowie i na wsi podkrakowskiej. Lud, 61, 130-145.

Czar nici (2020). Warsztaty Rękodzieła Artystycznego „Czar nici”. Pobrane z: http://www.haftkoronka.wordpress.com (1.07.2020).

Duś, E. (2011). Rola i miejsce ogrodów działkowych w przestrzeni miejskiej. Geographia. Studia et Dissertationes, 33, 79-100.

Encyklopedia PWN (2020). Pobrane z: https://encyklopedia.pwn. pl/haslo/kultura-ludowa;3934264.html (20.06.2020).

Figlus, T. (2020a). Process of incorporation and morphological transformations of rural settlements patterns in the context of urban development. The casestudy of Łódź. Quaestiones Geographicae, 39 (2), 75-95. https://doi.org/10.2478/ quageo-2020-0019

Figlus, T. (2020b). Transformacja morfologiczna wsi włączonych do miasta po II wojnie światowej na przykładzie Łodzi. Wieś i Rolnictwo, 2 (187), 99-130.

Frydryczak, B. (2011). Krajobraz: próba ujęcia w perspektywie interdyscyplinarnej. Studia Europea Gnesnensia, 4, 207-224.

Gajdek, A., Cieśla, B. (2017). Relikty układów ruralistycznych w strukturze współczesnego miasta. Zachowane dziedzictwo w kontekście założeń miasta przyszłości, na przykładzie Rzeszowa. Czasopismo Inżynierii Ladowej, Środowiska i Architektury, 64 (3/II), 67-78. https://doi.org/10.7862/rb.2017.154

Gałka, A. (2018). Ochrona kształtu wsi - czy warto włączać obszary wiejskie do granic administracyjnych okolicznych miast. Prace Naukowe Uniwersytetu Ekonomicznego we Wrocławiu, 504, 29-42. https://doi.org/10.15611/pn.2018.504.03

Geopartal krajowy (2020). Pobrane z: http://mapy.geoportal.gov. pl (17.02.2020).

Google Maps (2019). Pobrane z: http://www.google.com/maps (12.02.2019).

Górka, A. (2015). Wsparcie dla wiejskości. Znaczenie doświadczeń w kształtowaniu wiejskiego krajobrazu. Studia KPZK, $163,65-82$.

Grochulska-Salak, M. (2017). Rolnictwo miejskie jako element krystalizujący przestrzeń suburbiów. Kwartalnik Naukowy Uczelni Vistula, 4 (54), 153-161.

Grochulska-Salak, M. (2018). Rolnictwo miejskie jako innowacyjna produkcja stanowiąca element scalający i uzupełniający strukturę miasta. Budownictwo i Architektura, 17 (2), 143-158. https://doi.org/10.24358/Bud-Arch_18_172_12

Grochulska-Salak, M. (2019). Urban farming in sustainable city development. W: J.G. Vargas-Hernández, J. Zdunek-Wielgołaska, Bioeconomic alsolutions and investments in sustainable city development (s. 43-64). Hershey: IGI Global. https://doi. org/10.4018/978-1-5225-7958-8.ch003

Halamska, M. (2009). Uwagi o naturze wiejskości i sposobach jej definiowania. W: G. Gorzelak, M. Szczepański, W. Ślęzak-Tazbir, Człowiek-miasto-region. Zwiazki i interakcje. Księga jubileuszowa Bohdana Jałowieckiego (s. 123-136). Warszawa: Wydawnictwo Naukowe Scholar.

Halamska, M. (2011). Wiejskość jako kategoria socjologiczna. Wieś i rolnictwo, 1 (150), 37-55.

Handke, K. (1992). Polskie nazewnictwo miejskie. Warszawa: PAN Instytut Slawistyki.

Jeziorska-Biel, P. (2017). Społeczne i przestrzenne aspekty procesu odnowy wsi (przypadek województwa łódzkiego). Biuletyn KPZK, 267, 121-132.

Jędrysiak, T. (2010). Wiejska turystyka kulturowa. Warszawa: Polskie Wydawnictwo Ekonomiczne.

Kowalewski, A., Mordasewicz, J., Osiatyński, J., Regulski, J., Stępień, J., Śleszyński, P. (2014). Ekonomiczne i społeczne koszty niekontrolowanej urbanizacji w Polsce - wybrane fragmenty raportu. Samorzad Terytorialny, 25 (4/280), 5-21. 
Kozieł, A. (2003). Betlejem krakowskie. Dzieje szopki krakowskiej. Kraków: Wydawnictwo „m”.

Kraków Naszemiasto.pl (2020). Pobrane z: https://krakow.naszemiasto.pl (11.06.2020).

Krzyk, P. (2009). Obszary rolne jako element systemu przyrodniczego miasta Krakowa. Problemy Rozwoju Miast, 3, 47-61.

Krzyk, P., Bury, K. (2013). Zmiany przeznaczenia użytków rolnych Krakowa w miejscowych planach zagospodarowania przestrzennego. Problemy Rozwoju Miast, 4, 27-40.

Krzyk, P., Tokarczuk, T., Heczko-Hyłowa, E., Ziobrowski, Z. (2013). Obszary rolne jako element struktury przestrzennej miast - problemy planistyczne. Kraków: Instytut Rozwoju Miast.

Kwiecińska, M. (2014a). Emaus - tradycja krakowskiego pielgrzymowania. Krzysztofory, 32, 349-362.

Kwiecińska, M. (2014b). Konik zwierzyniecki jako obrzęd lokalny i uniwersalny. W: R. Klimek (red.), Świat Lajkonika. Konik na świecie (s. 178-188). Kraków: Muzeum Historyczne Miasta Krakowa.

Kwiecińska, M. (2017). Szopkarstwo krakowskie w procesach kształtowania dziedzictwa miasta. Zeszyty Naukowe Uniwersytetu Jagiellońskiego. Prace Etnograficzne, 45 (3), 333-350. https://doi.org/10.4467/22999558.PE.17.016.8360

Luchter, B. (2009). Tendencje zmian użytkowania ziemi w Krakowie w latach 1848-2008. Świat Nieruchomości, 1 (67), 30-37.

Luchter, B. (2010). Zmiany użytkowania ziemi na terenie wybranych jednostek przestrzennych, wchodzących w skład miasta Krakowa, w latach 1848-2008. Świat Nieruchomości, 1 (71), 4-11.

Luchter, B. (2012). Kraków - zarys przemian ekonomiczno-przestrzennych. Kraków: Wydawnictwo Uniwersytetu Ekonomicznego.

Luchter, B. (2011). Przemiany użytkowania ziemi w Nowej Hucie w okresie 60 lat jej istnienia. Świat Nieruchomości, 1 (75), 4-11.

Małopolska Infrastruktura Informacji Przestrzennej (2020). Pobrane z: https://miip.geomalopolska.pl (20.03.2020).

MAPSTER (2020). Pobrane z: http://igrek.amzp.pl/ (15.03.2020).

Michałowski, A. (2001). Świadome kształtowanie krajobrazu a ochrona krajobrazu historycznego. W: A. Michałowski (red.), Krajobraz kulturowy. Warsztaty dla nauczycieli i metodyków. Zeszyt dydaktyczny (s. 3-8). Warszawa: Ośrodek Ochrony Zabytkowego Krajobrazu.

Miszewska, B., Szmytkie, R. (2017). Rozwój przestrzenny i przemiany morfologiczne osiedli Wrocławia wyrosłych wokół dawnych wsi kmiecych. Studia z Geografii Politycznej i Historycznej, 6, 51-70. https://doi.org/10.18778/2300-0562.06.03

Mydel, R. (1979). Rozwój struktury przestrzennej miasta Krakowa. Wrocław: Zakład Narodowy im. Ossolińskich.

Mydel, R. (1994). Rozwój urbanistyczny miasta Krakowa po drugiej wojnie światowej. Kraków: Wydawnictwo „Secesja”.

Myga-Piątek, U. (2001). Spór o pojęcie krajobrazu w geografii i dziedzinach pokrewnych. Przeglad Geograficzny, 73, 1-2, 163-176.

Myga-Piątek, U. (2005a). Historia, metody i źródła badań krajobrazów kulturowych. W: A. Szponar, S. Horska-Schwarz (red.), Problemy Ekologii Krajobrazu XVII (s. 1-77). Wrocław: Uniwersytet Wrocławski.

Myga-Piątek, U. (2005b). Krajobraz kulturowy w badaniach geograficznych. Prace Komisji Krajobrazu Kulturowego PTG, 4, 40-53.

Myga-Piątek, U. (2012). Krajobrazy kulturowe: aspekty ewolucyjne i typologiczne. Katowice: Uniwersytet Śląski.

Nowakowski, S. (1963). Tendencje egalitarne i nowa hierarchia społeczna w przemysłowo-miejskim środowisku ziem zachodnich. Przeglad Socjologiczny, 17 (1), 35-52.

Oleszkiewicz, M. (2016). Magazyn obrzędów. Niematerialne dziedzictwo w muzeum na przykładzie śladów Emausu i Rękawki w zbiorach Muzeum Etnograficznego im. Seweryna Udzieli w Krakowie. W: M. Kwiecińska (red.), Niematerialne dziedzictwo miasta: muzealizacja, ochrona, edukacja (s. 157-169). Kraków: Muzeum Historyczne Miasta Krakowa.

Opracowanie Ekofizjograficzne Miasta Krakowa (2010). Miasto Kraków. Pobrane z: https://www.bip.krakow.pl/?dok_ id=115\&lid=900692606\& $\mathrm{vReg}=2$ (15.06.2020).

Państwowy Rejestr Nazw Geograficznych (2020). Pobrane z: http://www.gugik.gov.pl/ (20.06.2020).

Plit, F. (2011). Krajobraz kulturowy - czym jest? Warszawa: Uniwersytet Warszawski, Wydział Geografii i Studiów Regionalnych.

Plit, J. (2016). Krajobrazy kulturowe Polski i ich przemiany. Warszawa: PAN, Instytut Geografii i Przestrzennego Zagospodarowania.

Poczet Krakowski (2020a). Pobrane z: https://www.poczetkrakowski.pl/tomy/show_tome.html?tome=1 (1.06.2020).

Poczet Krakowski (2020b). Pobrane z: https://www.poczetkrakowski.pl/tomy/show_article,dzielnica-administracyjna-a-dzielnica-katastralna-1235.html (1.06.2020).

Poczet Krakowski (2020c). Pobrane z: https://www.poczetkrakowski.pl/granice-krakowa/ (1.06.2020).

Poczet Krakowski (2020d). Pobrane z: https://www.poczetkrakowski.pl/tomy/show_article,punkt-wyjscia-wielki-krakow-422. html (1.06.2020).

Podedworna, H. (2010). Wiejskość wyzwolona. Nowa konceptualizacja przestrzeni wiejskiej. Roczniki socjologii wsi, 29, 7-24.

Podedworna, H. (2013). Wiejskość jako obcość. W: D. Kasprzyk (red.), Nie tylko o wsi... Szkice humanistyczne dedykowane profesor Marii Wieruszewskiej-Adamczyk (s. 137-147). Łódź: Wydawnictwo Uniwersytetu Łódzkiego. https://doi. org/10.18778/7969-011-4.07

Radecka, E. (2016). Osadzanie Chochoła. Pomiędzy tradycją ludową a literacką. W: M. Kwiecińska (red.), Niematerialne dziedzictwo miasta: muzealizacja, ochrona, edukacja (s. 202-212). Kraków: Muzeum Historyczne Miasta Krakowa.

Rejestr Urzędowy Podziału Terytorialnego Kraju (TERYT) (2020). Pobrane z: https://eteryt.stat.gov.pl (25.06.2020).

Rocznik statystyczny Krakowa (2005). Urząd Statystyczny w Krakowie. Pobrane z: https://krakow.stat.gov.pl/publikacje-i-foldery/roczniki-statystyczne/rocznik-statystyczny-krakowa-2005,6,4.html (10.06.2020).

Rocznik statystyczny Krakowa (2007). Urząd Statystyczny w Krakowie. Pobrane z: https://krakow.stat.gov.pl/publikacje-i-foldery/roczniki-statystyczne/rocznik-statystyczny-krakowa-2007,6,3.html (10.06.2020).

Rocznik statystyczny Krakowa (2009). Urząd Statystyczny w Krakowie. Pobrane z: https://krakow.stat.gov.pl/publikacje-i-foldery/roczniki-statystyczne/rocznik-statystyczny-krakowa-2009,6,2.html (10.06.2020).

Rocznik statystyczny Krakowa (2011). Urząd Statystyczny w Krakowie. Pobrane z: https://krakow.stat.gov.pl/publikacje-i-foldery/roczniki-statystyczne/rocznik-statystyczny-krakowa-2011,6,1.html (10.06.2020).

Rocznik statystyczny Krakowa (2013). Urząd Statystyczny w Krakowie. Pobrane z: https://krakow.stat.gov.pl/rocznik-statystyczny-krakowa-2013-922/ (10.06.2020).

Rocznik statystyczny Krakowa (2015). Urząd Statystyczny w Krakowie. Pobrane z: https://krakow.stat.gov.pl/publikacje-i-foldery/roczniki-statystyczne/rocznik-statystyczny-krakowa-2015,6,6.html (10.06.2020).

Rocznik statystyczny Krakowa (2017). Urząd Statystyczny w Krakowie. Pobrane z: https://krakow.stat.gov.pl/publikacje-i-foldery/roczniki-statystyczne/rocznik-statystyczny-krakowa-2017,6,7.html (10.06.2020). 
Skiba, S., Drewnik, M. (2010). Kierunki rozwoju rolnictwa w granicach Krakowa. W: B. Degórska (red.), Opracowanie ekofizjograficzne miasta Krakowa (s. 255-264). Kraków: Urząd Miasta Krakowa.

Stownik języka polskiego pod red. W. Doroszewskiego (2020). Pobrane z: http://doroszewski.pwn.pl/haslo/wie\%C5\%9Bniak/ (20.06.2020).

Sobieska, T., Sobieska, K., Blondiau, G. (2003). Śladami Młodej Polski. Secesja w Krakowie i okolicach. Kraków: Wydawnictwo "Dęby Rogalińskie".

Sroka, W. (2013). Rolnictwo i gospodarstwa rolne w miastach - znaczenie i zakres zjawiska. Roczniki Naukowe SERiA, $X V(3), 317-322$.

Sroka, W. (2014a). Definicje oraz formy miejskiej agrokultury - przyczynek do dyskusji. Wieś i Rolnictwo, 3 (164), 85-103.

Sroka, W. (2014b). Struktura oraz intensywność użytkowania gruntów rolnych w miastach i na obszarach podmiejskich. Roczniki Naukowe SERiA, XVI (6), 449-455.

Sroka, W. (2015). Resources and use of agricultural land in Polish cities according to chosen theories of location of agricultural production. Acta Scientiarum Polonorum Oeconomia, 14 (3), 135-147.

Sroka, W. (2016a). Aktywność ekonomiczna i powiązanie z rynkiem gospodarstw rolnych zlokalizowanych w miastach oraz ich obszarach funkcjonalnych. Roczniki Naukowe SERiA, XVIII (5), 231-237.

Sroka, W. (2016b). Potencjał produkcyjny rolnictwa w miastach i obszarach podmiejskich. Roczniki Naukowe SERiA, XVIII (2), 249-255.

Sroka, W., Musiał, W. (2016). Rolnictwo i gospodarstwa rolne na obszarach miejskich i podmiejskich - konceptualizacja oraz przesłanki rozwoju. Folia Pomeranae Universitatis Technologiae Stetinensis, Oeconomica, 329 (84/3), 123-134. https://doi. org/10.21005/oe.2016.84.3.12

Studium uwarunkowań $i$ kierunków zagospodarowania przestrzennego Miasta Krakowa (2014). Miasto Kraków. Pobrane z: https:// www.bip.krakow.pl/?id=48 (15.06.2020).

Szałapak, A. (2012). Szopka krakowska jako zjawisko folkloru krakowskiego na tle szopki europejskiej. Studium historyczno-etnograficzne. Kraków: Muzeum Historyczne Miasta Krakowa.

Szkup, R. (2013). Użytkowanie rodzinnych ogrodów działkowych (ROD) przez społeczność wielkomiejska: przykład Łodzi. Łódź: Wydawnictwo Uniwersytetu Łódzkiego. https://doi. org/10.18778/7525-904-9

Szkup, R., Pytel, S. (2016). Ogrody działkowe (ROD) w przestrzeni dużego miasta. Przykład Łodzi. Prace Komisji Krajobrazu Kulturowego, 32, 109-124.

Szmytkie, R. (2011). Osiedla wiejskie w granicach administracyjnych dużego miasta (przykład Wrocławia). Studia Miejskie, 3/2011, 159-186.

Szmytkie, R. (2014). Metody analizy morfologii i fizjonomii jednostek osadniczych. Rozprawy Naukowe Instytutu Geografii i Rozwoju Regionalnego 35. Wrocław: Uniwersytet Wrocławski.
Szoka, A.I. (2014). Lajkonik - Konik Zwierzyniecki. Dzieje niematerialnego eksponatu muzealnego. W: R. Klimek (red.), Świat Lajkonika. Konik na świecie (s. 31-73). Kraków: Muzeum Historyczne Miasta Krakowa.

Szpakowska, E. (2011). Architektura miasta idealnego: wprowadzenie. Przestrzeń i Forma, 16, 121-154.

Szukaj w Archiwach (2020). Pobrane z: http://www.szukajwarchiwach.gov.pl/ (17.03.2020).

Szymańska, D., Biegańska, J. (2011). Fenomen urbanizacji i procesy z nim związane. Studia Miejskie, 4, 13-38.

Śleszyński, P., Komornicki, T., Deręgowska, A., Zielińska, B. (2014). Analiza stanu i uwarunkowań prac planistycznych w gminach w 2012 roku. Warszawa: Instytut Geografii i Przestrzennego Zagospodarowania PAN na zlecenie Ministerstwa Infrastruktury i Rozwoju.

Tkaczewski, D. (2016). „Narastanie miasta” na przykładzie Pragi. Fenomen i dynamizm czeskiej stolicy w XIX i pierwszej połowie XX w. Studia Ekonomiczne, 303, 183-202.

Ustawa z dnia 23 lipca 2003 r. o ochronie zabytków i opiece nad zabytkami. Dz.U. 2003, nr 162, poz. 1568.

Ustawa z dnia 24 kwietnia 2015 r. o zmianie niektórych ustaw w zwiazku ze wzmocnieniem narzędzi ochrony krajobrazu. Dz.U. 2015, poz. 774

Waltoś, S. (2000). Krajobraz „Wesela”. Kraków: Wydawnictwo Plus.

Wasilewski, J. (1986). Społeczeństwo polskie, społeczeństwo chłopskie. Studia Socjologiczne, 3 (102), 39-56 (przedruk: Studia Socjologiczne, 2011, 1 (200), 353-368).

Wieczorkiewicz, W. (1995). Planowanie przestrzenne osadnictwa wiejskiego. Warszawa: Wydawnictwo Szkoły Głównej Gospodarstwa Wiejskiego.

Wielki słownik języka polskiego (2020a). Pobrane z: https:// wsjp.pl/index.php?id_hasla $=3352 \&$ ind $=0 \& w_{-}$ szukaj=wiejsko\%C5\%9B\%C4\%87 (3.06.2020).

Wielki słownik języka polskiego (2020b). Pobrane z: https://wsjp.pl/index.php?id_hasla $=33302 \& i d \_z n a c z e n i a=3947230 \& l=27 \& i n d=0$ (3.06.2020).

Wilkaniec, A. (2018). Stan zachowania i trwałość historycznych układów przestrzennych dawnych wsi i majątków w strukturze Poznania. Poznań: Wydawnictwo Uniwersytetu Przyrodniczego w Poznaniu.

Wójcik, M. (2012). Geografia wsi w Polsce: studium zmiany podstaw teoretyczno-metodologicznych. Łódź: Wydawnictwo Uniwersytetu Łódzkiego. https://doi.org/10.18778/7525-657-4

Wójcik, M. (2013). Przemiany społeczno-przestrzenne osiedli wiejskich. Studium przypadku Łódzkiego Obszaru Metropolitalnego. Łódź: Wydawnictwo Uniwersytetu Łódzkiego. https://doi. org/10.18778/7969-047-3

Zbijewska, K. (1986). Krakowskim szlakiem Stanisława Wyspiańskiego. Warszawa: PTTK „Kraj”.

Artykuł wpłynął 20 lipca 2020

Zaakceptowano do druku:

1 grudnia 2020 